\title{
THE BAZAAR EFFECT, UNBUNDLING OF COMPARATIVE AdVANTAGE, AND MigRATION
}

\author{
WILHELM KOHLER
}

CESIFO WORKING PAPER No. 1932

CATEGORY 7: TRAdE POLICY

FEBRUARY 2007

An electronic version of the paper may be downloaded

- from the SSRN website:

- from the RePEc website:

- from the CESifo website:

www.SSRN.com

www.RePEc.org

www.CESifo-group.de 


\title{
THE BAZAAR EFFECT, UNBUNDLING OF COMPARATIVE AdVANTAGE, AND MigRATION
}

\begin{abstract}
Germany exhibits a strong reduction in domestic manufacturing production depth (bazaar effect). I argue that this reflects an unbundling of comparative advantage. Using a model where Ricardian plus Heckscher-Ohlin-type comparative advantage relates to fragments of production, I compare a trading equilibrium where all fragments are located within a country with an equilibrium where input sub-bundles may be traded (offshoring). The model allows for several goods and two fragments, produced with high-skilled and low-skilled labor. I address wage and welfare effects under flexible wages, and under a minimum wage. I also explore trade policy implications and compare offshoring to migration.
\end{abstract}

JEL Code: F11, F16, F22.

Keywords: comparative advantage, offshoring, outsourcing, globalization, migration.

\author{
Wilhelm Kohler \\ University of Tübingen \\ Nauklerstr. 47 \\ 72074 Tübingen \\ Germany \\ wilhelm.kohler@uni-tuebingen.de
}

February 2007

An earlier version of this paper was presented at the "36th Ottobeuren Economic Policy Seminar", held September 17-20, 2006. I have benefited from comments by several seminar participants. I am particularly grateful to Helmut Hesse for his comments prepared for the seminar. The present paper was partly written while I was visiting CESifo in Munich in November 2006, and the University of Paderborn in January 2007. I am grateful for the hospitality received at both places. I wish to thank Peter Egger, Wolfgang Eggert, Gabriel Felbermayr, Thomas Gries and Werner Sinn for stimulating comments and discussion. Thanks also to Hans-Jörg Schmerer for critical remarks on an earlier version, and for editorial assistance for the final version. I gratefully acknowledge financial support under a grant from Thyssen Foundation entitled "Migration and Labor Market Integration". 


\section{Introduction}

The German economy has recently exhibited strong export performance. However, two things have been pointed out that militate against a positive overall picture. The first is that the export boom has for a long time failed to feed into an improvement in domestic growth and higher employment, leading some observers to call it a "pathological" phenomenon. Only recently has German economic growth fallen somewhat more in line with its strong export performance. The second is that exports of German firms are based on ever thinner shares of German value added, with ever larger shares taking place in other countries. This latter feature has sometimes been cartooned as a trend towards a "bazaar economy", with a reduction in domestic production depth being dubbed a "bazaar-effect". ${ }^{1}$

The debate in Germany and elsewhere features two opposing views. One holds that the bazaar-effect reflects gainful structural adjustment to new global conditions, featuring new forms of international specialization and enhanced gains from trade, albeit with potentially large pains of adjustment in the form of a sharper earnings inequality between capital owners and different types of workers. The other view holds that the bazaar-effect reflects a detrimental loss of international competitiveness, caused by high and rigid wages as well as costly goods and labor market regulation.

Although such rigidity and regulation are no doubt characteristic of the German economy, they are unlikely to be the driving force behind bazaar-type phenomena. These are similarly observed in much more flexible economies, particularly the US. The bazaar-effect thus reflects a more general trend in international trade. Indeed, there is a whole strand of literature dealing with bazaar-type phenomena, which have variously been named outsourcing, offshoring, or fragmentation. The new element of trade stressed by this literature is the break-up of production processes and the possibility to locate certain parts or stages of production to other countries where cost conditions are more advantageous. The literature broadly falls into two lines of research. One focuses on wages and employment in countries where such phenomena arise. The other focuses on contractual imperfections relating to the (cross-border) fragmentation of industrial production, or provision of ser-

\footnotetext{
${ }^{1}$ The terms "bazaar economy" and "pathological export boom" have been coined by Sinn (2005a and 2005b), who also documents the empirical side of the debate.
} 
vices, that may explain why such fragmentation arises, and why it may arise in different organizational forms. ${ }^{2}$ This paper contributes to the first line of research in focusing on wage and employment implications of bazaar-type phenomena. ${ }^{3}$

The empirical literature conveys a relatively robust message: In high-income industrial countries, offshoring has had a significant negative effect on domestic wages of low-skilled labor, although the effect is relatively small in magnitude, leaving much room for other determinants of the wage trends observed. The intuition offered for this finding is that offshoring mainly involves relocation of (low-skill) labor-intensive parts of production to low-wage countries. ${ }^{4}$ This intuition also shapes much of the policy discussion. Yet, it is questionable theoretically. If firms move to low-wage countries for part of their production, they should experience a cost-saving effect. This may lead them to expand other parts of their production process that also use such labor, but for some reason cannot be relocated. In the short run, however, if factors cannot easily be reallocated across sectors, this costsaving effect is very unlikely to compensate for the direct labor demand effect. Hence, equilibrium most likely requires a fall in the domestic wage for low-skilled labor. ${ }^{5}$

But in the long run, reallocation of factors across different industries may change the outcome. Intuitively, if a certain industry obtains low-skill-intensive parts of its produc-

\footnotetext{
${ }^{2}$ The first strand of the literature dates back to Jones \& Kierzkowski (1990), more recent contributions are surveyed in Kohler (2003). Key kontributions to the second strand are Antràs \& Helpman $(2004,2006)$ and Grossman \& Helpman (2005). A very useful survey highlighting the above distinction is found in Helpman (2006).

${ }^{3}$ Following recent literature, I define outsourcing as a switch from "in-house-operation" of a sub-bundle of inputs to subcontracting it to an independent supplier. It thus relates to the organizational form of production. Offshoring relates to whether a sub-bundle draws on domestic or foreign factor markets, irrespective of the organizational mode. Fragmentation is a somewhat more general term relating to the separation of input-sub-bundles, without specifying what is "onshore" or "offshore". I use the terms fragmentation and unbundling interchangeably, although unbundling proves more useful in highlighting the notion of "bundling protection"; see below. Whether or not any of these phenomena gives rise to a bazaar-effect is yet another question, depending on whether we look at a single firm of industry, or at the economy at large.

${ }^{4}$ Feenstra \& Hanson (2004) survey industry level evidence for the US. Other evidence, including plantlevel and micro-data-evidence is surveyed in Görg \& Hanley (2005).

${ }^{5}$ This reasoning is substantiated in Kohler (2001,2004a), where I have analyzed the short-run effects using a Ricardo-Viner model.
} 
tion at lower cost from offshore, then, with a constant price of its good, this mandates higher income paid to factors employed in other parts of $i t s$ production. This follows from the zero-profit condition of a long-run equilibrium. But these other parts may well be relatively intensive in low-skilled labor compared to other industries where offshoring is no option, or indeed to the economy at large. Then, if factors are mobile across sectors, Stolper-Samuelson logic implies that low-skilled labor gains. ${ }^{6}$

In this paper, I propose to frame this line of reasoning in terms of unbundling comparative advantage. A surprisingly large part of the literature on offshoring makes no explicit, or very little reference to comparative advantage. I argue that additional insights may be obtained by bringing comparative advantage more prominently into the picture. Conventional theory of comparative advantage views a production process as a cost-minimizing bundle of inputs, say high-skilled and low-skilled labor, per unit of a marketable output, given a single set of factor prices. Ricardian theory stresses that minimum costs may differ because of differences in technologies. Heckscher-Ohlin theory stresses that they are different across countries if relative factor prices differ, even if technologies are the same. So called "modern" theory of trade and agglomeration would add that it also depends on pecuniary externalities, due to forward- and backward linkages that arise where there are fixed costs and variety effects on the materials input side. In this case, an additional bundling dimension is present: The productivity of any one firm in a given sector depends on the number and types of firms that are bundled together in a country. ${ }^{7}$

In equilibrium, if a given production process is operated in two separate locations, or countries, then the difference between the income earned by a unit-output factor bundle in these two locations must reflect the Ricardian productivity difference plus any productivity difference deriving from agglomeration. If the number of processes operated jointly in the two locations is at least as large as the number of factors, then the same must be true for each factor separately - the case of factor price equalization through trade. The productivity of such input bundles across different goods, together with the corresponding factor intensities, determine what general equilibrium theory calls the country's factor price frontier. This describes alternative factor price combinations mandated by the country's technological knowledge, given goods prices on world markets.

\footnotetext{
${ }^{6}$ In Kohler (2003 and 2004a), I derive general long-run results for a Heckscher-Ohlin model.

${ }^{7}$ For a general discussion of this modern view of "bundling", see Baldwin (2006b).
} 
But a typical modern industrial process is ineptly described in terms of a single, coherent input bundle. Suppose, then, that the unit-output-bundle of inputs may be decomposed into several sub-bundles. Suppose, moreover, that these sub-bundles differ in terms of factor intensity, and countries are differently efficient on the level of subbundles. In what follows, I shall alternatively use the terms sub-bundles, fragments, or stages of a production process. Certain stages where a country boasts high efficiency relative to other countries may thus be bundled with other, low efficiency bundles. In a similar vein, a country's factor prices relative to those of other countries may confer different degrees of (dis)advantage for various such sub-bundles of inputs. In this way, certain sub-bundles may receive "protection" from being bundled with others. I call this "bundling protection" afforded by the costs of unbundling. By costs of unbundling, I mean any additional resource use that would follow from locating sub-bundles of inputs in different countries. We must think of these as the minimum cost of whatever is the most economical organizational, or contractual, arrangement for such unbundling.

An equilibrium with bundling-protection is disturbed by a sufficiently large reduction of the costs of unbundling. Such a reduction may be brought about by technological improvements in transport and communication, or by an improvement of institutions for sub-contracting. Loss of bundling-protection implies a new equilibrium, both in terms of the country's factor prices and its output pattern and, thus, trade. This may be called an equilibrium with unbundled comparative advantage. It can be described with the aid of a new factor price frontier, based on a potentially large number of unit-output sub-bundles of inputs for each good, instead of a single aggregate input bundle.

Unbundling involves a bazaar-effect in that it reveals a country's comparative disadvantage in fragments that have hitherto enjoyed bundling protection and which, deprived of this protection, are lost to other countries. This alters domestic factor demand. Firms that move the less skill-intensive lines of their production offshore now demand less lowskilled labor, which clearly puts downward pressure on wages for this country's low-skilled workers. However, unbundling also implies that other fragments of various production processes in this same country will be "freed up" to their full comparative advantage. If the overall unbundling scenario is such that the fragments relieved from a "bundlingburden" use much low-skilled labor, relative to the economy's overall endowment ratio, then the wage pressure on low-skilled workers will be alleviated. This, in essence, is the general equilibrium channel for what is often called the cost-savings potential, or the 
productivity effect of offshoring. Indeed, the analysis below reveals that under certain conditions low-skilled labor may even gain from such unbundling.

If looked at in this way, a bazaar-effect in any one industry need not imply that the industry as a whole shrinks. Depending on the position of the fragment freed up to full comparative advantage within the economy's cone of diversification, it may expand in terms of output sold on world markets. The same applies for the individual firm which may well thrive while shedding labor on fragments that have fallen victim to international unbundling. The principle of arbitrage that leads to bazaar-type phenomena simply operates on a level which is different from the firm or the sector. This has potentially serious policy implications. In particular it may undermine policies that rely on the traditional, bundled view of the world, such as for instance policies geared towards fostering particular industries that for whatever reason seem attractive to a country's policy makers. The outcomes of such policies have become less predictable and the policies, therefore, more error prone. ${ }^{8}$

In this paper, I use a model incorporating Heckscher-Ohlin and Ricardian determinants of trade, in order to trace out the impact of unbundling comparative advantage on factor prices and factor allocation. The model assumes two types of labor, high-skilled and low-skilled, and it focuses on two countries' "local" comparative advantage. The two countries, labeled "West" and "East" are assumed to be embedded in world markets for tradable (final) goods where they face given prices. I first describe an equilibrium for bundled comparative advantage in terms of sub-bundles of inputs, but assuming that unbundling is prohibitively costly (section 2). Then I allow for unbundling and compare the two equilibria, assuming that wages are free to adjust (section 3). I explore the wage and welfare effects, as well as the labor re-allocation resulting from unbundling. I then redo the analysis under the assumption of a real wage rigidity for low-skilled labor (section 4). And finally, I draw some general conclusions that emerge from the analysis with a view on trade policy (section (5) and immigration (section 6).

How does the paper relate to the voluminous literature on offshoring? It draws on Jones (2000) in adapting the Lerner-Pearce diagram to depict fragmentation of production. Jones (2000) also was the first to emphasize that international fragmentation allows

\footnotetext{
${ }^{8}$ See the general discussion in Baldwin (2006b).
} 
countries to uncouple superior fragments of their production processes. Further important papers along these same lines are Jones \& Kierzkowski (2000), Deardorff (2001a,2001b), and Jones (2005). The contribution of this paper, relative to these earlier ones, is to provide a full analysis of a two country equilibrium with bundled versus unbundled comparative advantage. In line with Deardorff (2004), comparative advantage is defined as "local" concept in a many-country world with real trade costs. The analysis is aimed at general propositions on how the long-run wage and welfare effects of unbundling relate to the pattern of offshoring. I have already derived such propositions in Kohler (2003), where I allow for an arbitrary number of goods, factors and fragments, or sub-bundles of inputs. Here, I sharpen the insight by reducing dimensions, and by a closer focus on Heckscher-Ohlin plus Ricardian comparative advantage in a two-country setup. Ricardian comparative advantage with traded inputs is also treated, although in a somewhat different manner, by Deardorff (2005b). The idea that Ricardian differences across countries in terms of efficiency, an important element of my story, has also been stressed by Deardorff (2005a).

Framing my analysis in terms of unbundling allows me to bring into sharp analytical focus the cost-savings, or productivity effect of offshoring. The key role of this effect in shaping the wage effects from offshoring has been stressed in two recent papers by Grossman \& Rossi-Hansberg (2006a,2006b) who propose to view offshoring as trade in tasks (rather than trade in goods). ${ }^{9}$ The similarity between the notion of tasks and subbundles of inputs is obvious, but there is also a crucial difference, as will become evident below. The notion of unbundling, already implicit in Jones (2000), has recently been taken up by Baldwin $(2006 \mathrm{~b}, 2006 \mathrm{c})$, in order to identify novel features of globalization. He interprets the new paradigm of trade in tasks introduced by Grossman \& Rossi-Hansberg

\footnotetext{
${ }^{9}$ Grossman \& Rossi-Hansberg (2006a) contains a more policy oriented discussion plus some empirics, while its theoretical model is a somewhat stripped down version of Grossman \& Rossi-Hansberg (2006b). The productivity effect of offshoring is often alluded to in the public debate, and it has been taken up quite prominently in the empirical literature. See for instance Amiti \& Wei (2005a,2005b) and Görg \& Girma (2005). I am greatful to Helmut Hesse who has stressed this point in his comments at Ottobeuren, and also in private conversation, drawing my attention to empirical evidence on the productivity enhancing effects of German FDI and outsourcing; see Deutsche Bundesbank, "German foreign direct investment (FDI) relationships: recent trends and macroeconomic effects", Monthly Report, September 2006, pp. 43 - 83, particularly p. 53 .
} 
(2006b) as unbundling and contrasts this with what he calls "Mankiw-offshoring", where the key aspect is that tradability is extended into the realm of formerly non-tradable intermediates, with a wage effect that is equivalent - and equally ambiguous - to that of technological progress. In some sense, the present paper is firmly rooted in this earlier view, which I would call the Jonesian paradigm. However, I show that this paradigm may usefully be combined with Baldwin's notion of unbundling. And I show that the ambiguity can be resolved, partly at least, through propositions that tell us how certain general patterns of unbundling determine the attendant wage effects.

\section{Bundled Comparative Advantage}

Throughout this paper, comparative advantage relates to production, not trade. I assume that domestic demand in the countries is considered negligible for the determination of world-market prices for goods. Hence, demand - and thus trade - of these countries has no influence on their wages and employment. Moreover, comparative advantage is defined as a "local" concept, relating to two neighboring countries embedded in a larger world. As argued by Deardorff (2004), defining comparative advantage in this way is justified if trade costs between any one of these two countries and the rest of the world is significantly larger than between the two countries themselves. In my analysis, this applies to the geographical separation of individual fragments of production. Thus, in this paper comparative advantage is all about "who does what" in two neighboring countries, each facing given world-market prices for final goods. This section describes a conventional equilibrium with bundled comparative advantage, assuming that the entire bundle of inputs must always be sourced domestically. The subsequent section then considers an equilibrium where comparative advantage is unbundled, such that it incorporates costminimization through cross-country sourcing of sub-bundles of inputs. Comparing the equilibria with bundled and unbundled comparative advantage allows us to explore how unbundling affects factor prices and employment.

It will become evident that allowing for a minimum amount of industrial diversity in terms of offshoring characteristics is crucial for the wage effects of unbundling. I assume four final goods, $i=0, \ldots 3$, and I allow for potential unbundling only in two of the four goods, goods 1 and 2 . This may reflect prohibitive costs of separating fragments, or a fundamental characteristic of technology in producing goods 0 and 3 . It is meant to capture 
the obvious fact that industries have different "offshoring propensities". For simplicity, I assume only two sub-bundles, or fragments, and two factors, high-skilled and low-skilled labor, which are immobile between countries, but perfectly mobile across goods. Migration will be discussed towards the end of the paper. Firms have no market power on either output or input markets. I will also assume that unbundling comparative advantage between these countries as such does not affect world market prices. In view of the bazaar-economy-discussion mentioned in the introduction, what I have in mind is countries like Germany, henceforth called the "West", and nearby Eastern European countries, who are collectively referred to as the "East". With this interpretation, assuming given world market prices for traded final goods is a reasonable simplification.

I simplify by assuming Leontief-type production functions. For industries $i=1,2$ in the West, output $y_{i}$ depends on high-skilled and low-skilled labor inputs $L_{i s}$ as follows:

$$
\begin{aligned}
y_{i}\left(L_{i h}, L_{i l}\right) & =\min _{s=h, l}\left(a_{i s}^{-1} L_{i s}\right) \\
& =g_{i}\left(L_{i A h}, L_{i A l}, L_{i B h}, L_{i B l}\right)=\min _{r=A, B}\left[f_{i r}^{-1} \min _{s=h, l}\left(a_{i r s}^{-1} L_{i r s}\right)\right] .
\end{aligned}
$$

In these expressions, $s=h, l$ denotes high-skilled and low-skilled labor. Thus, $a_{i s}$ denotes type-s-labor input requirement per unit of final good $i$. I call $a_{i s} / a_{i l}$ the aggregate skillintensity of good $i$. In the second line, $f_{i r}$ denotes the input requirement of a type- $r$ fragment in good $i$ production, while $a_{i r s}$ indicates the type-s-labor input requirement per "unit" of fragment $r$. With bundled comparative advantage, equilibrium may be described relying only on (1), with unbundled comparative advantage, we must rely on (2). In the following, I shall occasionally use

$$
g_{i r}=g_{i r}\left(L_{i r h}, L_{i r l}\right)=\min _{s=h, l}\left(a_{i r s}^{-1} L_{i r s}\right)
$$

to denote the "level of production" of fragment $r$ in industry $i$, although there need not be a tangible output associated with a fragment. Outputs in industries 0 and 3, may be described according to simple expressions similar to (1), but without any decomposition into sub-bundles as in (2). ${ }^{10}$

\footnotetext{
${ }^{10}$ The model can be interpreted in a more general and somewhat more satisfactory way by assuming that capital as a third factor is separable from labor inputs and adjusts endogenously according to a standard neoclassical production function, and an appropriate no-arbitrage condition that reflects perfect international capital mobility with a given capital rental in terms of the numéraire.
} 
Although I use $A$ and $B$ to denote the two fragments in both goods, fragment $A$ of good-1-production may be a wholly different type of activity from fragment $A$ in good-2production. Skill-intensities drive the Heckscher-Ohlin mechanism of offshoring. Without loss of generality, I assume fragment $A$ to be the more skill-intensive one in both industries. In addition, I assume Ricardian productivity differences on the level of fragments, as in Jones (2000) and Deardorff (2005a). I assume these to be Hicks-neutral. Using an asterisk to denote the East, we thus have

$$
f_{i r}^{*}=\rho_{i r} f_{i r} \quad \text { with } \quad \rho_{i r}>0 .
$$

I do not assume that $\rho_{i r} \geq 1$ for all $i$ and $r$, hence there may be certain activities within an industry where the East has superior productivity. It should be noted that $a_{i r s}=a_{i r s}^{*}$ for all $i, r$ and $s$. Thus, Ricardian differences are restricted to the "fragment-productivities" $1 / f_{i r}$. With such Ricardian productivity gaps, the two countries may produce any one good with a different aggregate skill-intensity. I assume good 1 to be more skill-intensive than good 2 in both countries.

Factor endowments in terms of efficiency units are denoted by $E_{h} / E_{l}$ and $E_{h}^{*} / E_{l}^{*}$, and are assumed to be constant. For the Heckscher-Ohlin part of my story, I assume that

$$
E_{h} / E_{l}>E_{h}^{*} / E_{l}^{*} \quad \text { with } \quad w_{h} / w_{l}<w_{h}^{*} / w_{l}^{*},
$$

where $w_{s}$ and $w_{s}^{*}$ denote wage rates in the two countries, with $s=h(l)$ for high-skilled (low-skilled) labor. In the analysis below, whenever I state that the West (East) has an efficiency advantage in a certain activity, this means that an equal amount of efficiency units of both types of labor generates a larger output in the West than the East (East than the West). An efficiency advantage in the East is perfectly consistent with the East using a larger amount of physical units of labor than the West. Lower wages for physical units of both high-skilled and low-skilled labor are thus interpreted as reflecting Harrod-neutral technological superiority of the West.

I use $p_{i}$ to denote the given price of good $i$ relative to good 2 which is the numéraire. Equilibrium requires that firms in each country make zero-profits on goods produced, and have minimum unit-cost in excess of prices for all goods not produced domestically. With perfect wage flexibility, equilibrium also requires full employment. In a subsequent section, I shall also look at the case where a minimum real wage rate causes unemployment in the West. With complete bundling, zero-profits imply

$$
p_{i} \leq a_{i h} w_{h}+a_{i l} w_{l} \quad \text { and } \quad p_{i} \leq a_{i h}^{*} w_{h}^{*}+a_{i l}^{*} w_{l}^{*}, \quad i=0 \ldots 3 \text {, }
$$


with associated complementary slackness conditions stating that outputs $y_{i}$ or $y_{i}^{*}$ are zero if strict inequalities apply. Full employment requires

$$
a_{0 h} y_{0}+a_{1 h} y_{1}+a_{2 h} y_{2}+a_{3 h} y_{3}=E_{h} \quad \text { and } \quad a_{0 l} y_{0}+a_{1 l} y_{1}+a_{2 l} y_{2}+a_{3 l} y_{3}=E_{l}
$$

and accordingly for the East. The aggregate skill-intensity of any good can be expressed as a weighted average of the skill-intensity of individual components, with the relative importance of these components serving as weights: ${ }^{11}$

$$
a_{i h} / a_{i l}=\alpha_{i A}\left(a_{i A h} / a_{i A l}\right)+\alpha_{i B}\left(a_{i B h} / a_{i B l}\right) .
$$

Given world market prices, conditions (6) and (7) determine wage rates and output levels for the East and the West. In equilibrium, each country produces a subset of goods, depending on its technology, its factor endowment, and - potentially - on its trade policy. With two primary factors and 4 goods, equilibrium output levels need not be unique, as is well known, but for a large part of my analysis this indeterminacy is no problem. At this stage, I make no special assumption about the specific production pattern in the two countries. ${ }^{12}$ I do assume, however, that the trading equilibrium features a wage gap as given in (5). The wage gap is, of course, endogenous. But assuming $w_{h} / w_{l}<w_{h}^{*} / w_{l}^{*}$ makes sense empirically, and assuming it directly poses no analytical problem, while making the analysis easy. Of course, with arbitrary Ricardian differences and/or differences in tastes between East and West, and with arbitrary trade policies (if any) of the two countries, a trading equilibrium could well exhibit an opposite wage inequality, even with $E_{h} / E_{l}>E_{h}^{*} / E_{l}^{*}$, or it could feature factor price equalization. Therefore, assuming $w_{h} / w_{l}<w_{h}^{*} / w_{l}^{*}$ for the bundled comparative advantage trading equilibrium implies an unspecified restriction on the underlying differences in endowments and technology. Loosely speaking, I assume that endowment differences dominate the factor price differences that remain in the trading equilibrium.

\footnotetext{
${ }^{11}$ It can be shown that $a_{i h} / a_{i l}=\alpha_{i A}\left(a_{i A h} / a_{i A l}\right)+\alpha_{i B}\left(a_{i B h} / a_{i B l}\right)$, where $\alpha_{i A}=\tilde{\alpha}_{i A} /\left(\tilde{\alpha}_{i A}+\tilde{\alpha}_{i B}\right)$ and $\alpha_{i B}=\tilde{\alpha}_{i B} /\left(\tilde{\alpha}_{i A}+\tilde{\alpha}_{i B}\right)$, with $\tilde{\alpha}_{i A}=f_{i A} / f_{i B}$ and $\tilde{\alpha}_{i B}=a_{i B l} / \alpha_{i A l}$. We have $\alpha_{i A}+\alpha_{i B}=1$, hence the aggregate skill-intensity of final good $i$ is a weighted average of the skill-intensities of fragments $A$ and $B$. Notice that my Ricardian differences in technology imply that $\tilde{\alpha}_{i B}^{*}=\tilde{\alpha}_{i B}$, while $\tilde{\alpha}_{i A}^{*}=\tilde{\alpha}_{i A}\left(\rho_{i A} / \rho_{1 B}\right)$.

${ }^{12}$ For the analysis to make sense, I must assume that both the East and West produce at least one of the two goods 1 and 2 .
} 
The zero-profit conditions (6) assume that the same final goods prices hold in the East and the West. In other words, it assumes free trade. It will become obvious as I go along that the analysis is easily extended to the case where each of the two countries runs its own trade policy, whence world market prices would simply be replaced by policy-distorted domestic prices in the West and the East. I shall return to a consideration of some trade policy issues in the section 5 below.

What is the economic value generated by the sub-bundle of inputs $\left\{a_{1 B h}, a_{1 B l}\right\}$ in the West? With complete bundling, its value derives from being combined, domestically, with sub-bundle $\left\{a_{1 A h}, a_{1 A l}\right\}$ towards production of good 1 . Given wage rates $\left\{w_{h}, w_{l}\right\}$, this value may be written as

$$
\pi_{1 B}\left(w_{h}, w_{l}\right) \equiv\left[p_{1}-f_{1 A}\left(a_{1 A h} w_{h}+a_{1 A l} w_{l}\right)\right] / f_{i B} .
$$

A reciprocal definition holds for fragment $A$. In what follows, I call $\pi_{i r}\left(w_{h}, w_{l}\right)$ the implicit (or imputed) price of fragment $r$ under complete bundling of production 1 within the West. 13 With this definition, we may rewrite the zero-profit condition for good 1 in the West as

$$
\pi_{1 B}\left(w_{h}, w_{l}\right)=a_{1 B h} w_{h}+a_{1 B l} w_{l},
$$

assuming that good 1 is produced in the West. This states that the value generated by a "unit" of fragment $B$ in industry 1 is equal to its cost. This same condition can also be expressed in terms of the implicit price of fragment $A, \pi_{1 A}\left(w_{h}, w_{l}\right)$. Bundled comparative advantage rules out all trade in these fragments. The implicit price derives from being bundled, within the same country, with the other fragment. With this definition of $\pi_{1 B}$, the bundle $\left\{a_{1 B h} / \pi_{1 B}, a_{1 B l} / \pi_{1 B}\right\}$ of labor used for fragment $B$ represents an activity with an imputed value equal to 1 .

For both countries to have the same minimum unit-cost for good 1, we must have

$$
\sum_{r=A, B} f_{1 r}^{*}\left(a_{1 r h} w_{h}^{*}+a_{1 r l} w_{l}^{*}\right)=\sum_{r=A, B} f_{1 r}\left(a_{1 r h} w_{h}+a_{1 r l} w_{l}\right) .
$$

With (4), this puts a restriction on $\rho_{1 A}$ and $\rho_{1 B}$ that depends on the international difference in wage rates, $\left\{w_{h}, w_{l}\right\}$ and $\left\{w_{h}^{*}, w_{l}^{*}\right\}$ with inequality as in (5), given the Leontief-

\footnotetext{
${ }^{13}$ The notion of an implicit price is crucial for my analysis. In Kohler (2003,2004a), I have used the term effective price. See also Deardorff (2005a). There is an obvious analogy to the effective price in the theory of effective protection; see Ethier (1977).
} 
coefficients for the two fragments involved. A corresponding restriction obtains for good 2 to be viable in both the East and the West. A possible equilibrium with fully integrated processes and both countries producing goods 1 and 2 is depicted in figure 1, where goods 0 and 3 are assumed to be at the opposite extremes of the skill-intensity ranking. I use $L_{h}$ and $L_{l}$ as generic terms to indicate amounts of high-skilled and low-skilled labor on the two axes. The L-shaped isoquants represent aggregate factor bundles that generate a unit value of the respective good, given commodity prices and the respective country's technology. The production pattern and wage rates for an equilibrium with bundled comparative advantage now depend on the two country's endowment ratios. In particular, the wage ratios $w_{h} / w_{l}$ and $w_{h}^{*} / w_{l}^{*}$ may be read off the slope of the convex hull connecting a country's unit-value isoquants where it intersects with that country's endowment ray; see Jones $(2000,2005)$. The convex hulls are ZVUTS for the West, and ZVB*TS for the East. It is easy to envisage such endowment rays leading to the equilibrium wage rates depicted in figure 1 , with $w_{h} / w_{l}<w_{h}^{*} / w_{l}^{*}$ as assumed in (5).

Let us first briefly look at the West. An integrated labor bundle corresponding to the line segment $O B$, with an aggregate skill-intensity equal to $\alpha_{1 h} / a_{1 l}$, has unit-cost and it generates unit-value in industry 1 . This is composed of two sub-bundles corresponding to the two line segments $O A$ and $A B$. The bundle $O A^{\prime}$ represents a factor bundle with implicit unit-value, i.e., $\left\{a_{1 A h} / \pi_{1 A}, a_{1 A l} / \pi_{1 A}\right\}$ with the implicit price $\pi_{1 A}$ defined in complete analogy to $\pi_{i B}$ above. One might also view this factor bundle as belonging to a unit-valueadded isoquant for the final good 1 , treating fragment $B$ as a required intermediate good, alongside labor in fragment $A$, and assuming that the intermediate is obtained from domestic producers who make zero-profits. ${ }^{14}$ To avoid clutter, the corresponding unit-value labor bundles for other Western fragments are not drawn.

In the case depicted, since the aggregate skill-intensity of good 1 exceeds the ratio $\bar{a}_{h} / \bar{a}_{l}$, defined by the intersection of the two factor price lines, the East has a costdisadvantage in good 1 from a relatively higher wage for high-skilled labor ${ }^{15}$. But this is offset by sufficiently large Ricardian advantage in fragment $B$, i.e., by $\rho_{1 B}<1$, leading to an Eastern unit-value isoquant with vertex $B^{*}$, as opposed to $B$ for the West. The

\footnotetext{
${ }^{14}$ Compare this to Deardorff (2005a, p.264). See also Jones (2000).

${ }^{15}$ This critical ratio $\bar{a}_{h} / \bar{a}_{l}$ corresponds to the intersection point of the two factor price lines. Thus, $\bar{a}_{l}=\left(1 / w_{h}^{*}-1 / w_{h}\right) /\left(w_{l}^{*} / w_{h}^{*}-w_{l} / w_{h}\right)$, and analogously for $\bar{a}_{h}$.
} 
corresponding fragment-A-bundle with a unit-implicit-value, i.e., $\left\{a_{1 A h} / \pi_{1 A}^{*}, a_{1 A l} / \pi_{1 A}^{*}\right\}$, is given by point $A^{\prime *}$. This implies an absolute disadvantage for the East in fragment $A$. A uniform Ricardian advantage of the East across both fragments, $\rho_{1 A}=\rho_{1 B}<1$, with zero-profits with the same Eastern wage rates, would imply a unit-value isoquant with vertex at point $B^{0}$. A case where $\rho_{1 A}=1$, with $\rho_{1 B}$ sufficiently below unity would lead to a vertex at $C$. Similar reasoning applies for points to the right of $B^{0}$ on a line with slope $w_{l}^{*} / w_{h}^{*}$.

Figure 1: Bundled comparative advantage and factor prices with offsetting Ricardian efficiency gaps

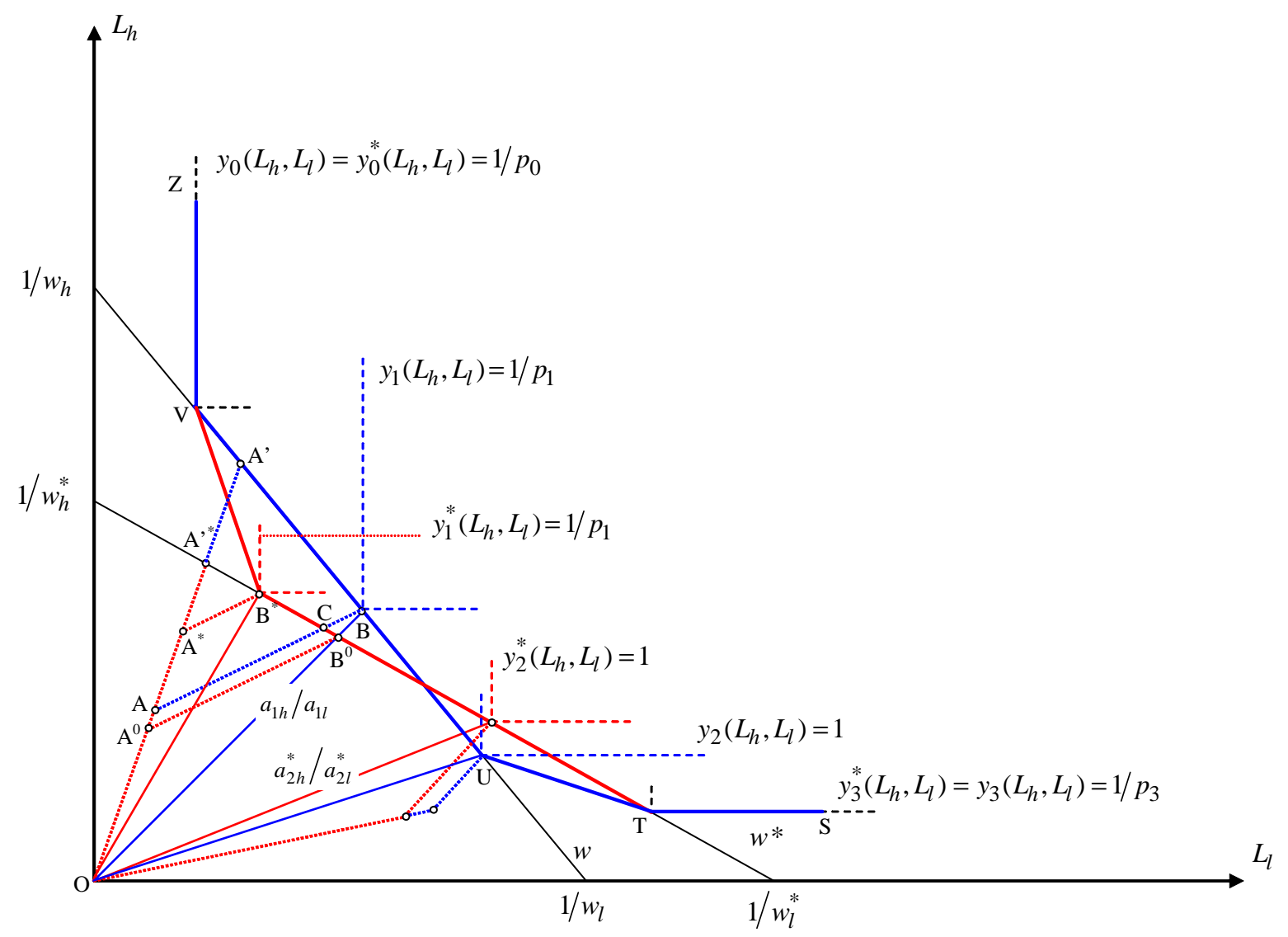

Figure 1 depicts a trading equilibrium with bundled comparative advantage, whereby the East has a relatively inefficient fragment $A$. This is further aggravated by the fact that fragment $\mathrm{A}$ is relatively skill-intensive, but the fragment receives implicit protection from being bundled with fragment $B$, where the East is relatively efficient, and where 
the cost disadvantage from its relatively expensive high-skilled labor is less severe. In a similar vein, the figure assumes that in industry 2 the West is technologically superior in the relatively skill-intensive fragment $A$ in industry 2 , which by assumption exhibits a lower aggregate skill-intensity than industry 1, and also a skill-intensity lower than $\bar{a}_{h} / \bar{a}_{l}$. Assuming a Ricardian efficiency advantage of the West in the relatively highskill-intensive fragment $A$, and conversely for fragment $B$, i.e., $\rho_{2 A}>1>\rho_{2 B}$, the West produces good 2 with a lower aggregate skill-intensity than the East, where we observe $a_{2 h}^{*} / a_{2 l}^{*}$ as depicted. ${ }^{16}$ An important upshot of the Ricardian element in my story is what I call a "thick margin" of comparative advantage: Even with wage rates differing across countries, there is more than one industry which is viable in both countries, which is an obvious fact in reality. ${ }^{17}$

In the case depicted, within each of the two industries each of the two countries has a Ricardian advantage in the activity that uses its relatively abundant (and relatively cheap) factor more intensively. As a result, both industries operate in a less skill-intensive manner in the skill-abundant West. Similarly, in the East which is abundant in low-skilled labor, both industries are operating with a lower ratio of low-skilled to high-skilled workers. For subsequent reference, I call this a case with offsetting Ricardian efficiency gaps, since the comparative advantage from the endowment difference is mitigated by the fact that the more skill-abundant country produces all goods with a lower skill-intensity than the country where skills are relatively scarce.

It might seem natural to anchor fragment-related Ricardian differences in this way, particularly if factor price differences themselves derive from given fundamental technological differences, as in Deardorff (2005a), or if endowments are endogenous to technological differences, due to international factor movements, as in Markusen (1983). However, the pattern of $\rho_{i r}$ should be seen as endogenous. In the present context, an argument can be made that they should be endogenous to factor price differences and, thus, to endowments. The thrust of this argument, in brief, runs as follows. First, methods to enhance productivity of certain sub-bundles of inputs should be viewed as an integral part of technological knowledge which is universally available. The challenge, then, is to explain a certain pat-

\footnotetext{
${ }^{16}$ Remember that our definition of the efficiency parameters is such that an absolute advantage in the West implies $\rho_{i r}>1$.

${ }^{17}$ Deardorff (1979) was among the first to explore such equilibria.
} 
tern of $\rho_{i A} \neq 1$ across fragments in equilibrium. Any $\rho_{i r}<1$ (or $\rho_{i r}>1$ ) means that firms in the West (East) forgo a technological improvement that firms in the East (West) have secured in fragment $r$ of industry $i$. Obviously, patent protection is implausible for such efficiency gaps. Then, for a case with $\rho_{i r}<1$ (and thus $f_{i r}>f_{i r}^{*}$ ) to be an equilibrium, the marginal cost of efficiency improving efforts in the West need to be larger than the marginal benefits from the resulting reduction in the per-unit requirement of fragment $r$ in industry $i$. Similarly for $\rho_{i r}>1$ in the East. Suppose, therefore, that efforts towards increasing productivities $1 / f_{i r}$ and $1 / f_{i r}^{*}$ require different proportions of high- and low-skilled labor for $r=A, B$. If $w_{h} / w_{l}<w_{h}^{*} / w_{l}^{*}$, as assumed, and if efforts towards productivity improvements in the more (less) skill-intensive fragments $A$ are themselves also more (less) skill-intensive, then the wage gap inflicts a relative cost-disadvantage on the West for efficiency-improving efforts in fragments $B$, and conversely for the East. In this way, the incentive for improving efficiency in skill-intensive fragments may peter out in the East even with $\rho_{i A}>1$. Conversely for the West with $\rho_{1 B}<1$. This corresponds to the case assumed in figure 1, which I have called offsetting Ricardian efficiency gaps above. An opposite skill-intensity pattern of productivity-enhancing efforts would suggest an opposite pattern of efficiency gaps, with $\rho_{i A}<1$, i.e., relative inefficiency of the West in skill-intensive fragments. As a result, the more skill-abundant West would need more of the skill-intensive fragment per unit of output produced of any one good than the East. The West would then also exhibit a larger aggregate skill-intensity in both industries, 1 and 2. I refer to this case as reinforcing Ricardian efficiency gaps.

Given the wage inequality between East and West, the pattern of efficiency gaps is crucial for the pattern of bundling protection that is implicit in an equilibrium with bundled comparative advantage. It will, therefore, also be crucial for the wage and employment effects of unbundling considered in the next section. I do not want to tie my analysis any specific pattern of $\rho_{i r}$. The propositions to be derived below can be interpreted against the backdrop of the distinction between offsetting and reinforcing patterns.

\section{Unbundling of Comparative Advantage}

In his recent paper on globalization, Baldwin (2006b) notes that "economists really do not understand the 'glue' that binds production stages and tasks together" (p.29). Up to this point, I have simply assumed that there is no effective 'glue' across country borders. 
Unbundling now implies that cross-border gluing is possible between West and East. More specifically, I assume it is possible between different fragments, or input-sub-bundles, but not between different types of labor directly. This is an important assumption, as will become evident below. Also, the glue is likely to be costly. In analytical terms, this may be captured by a suitable reinterpretation of $\rho_{i r}$ which describes productivity of an Eastern input-sub-bundle $r$ in process $i$, relative to Western productivity. One may now interpret a higher or lower value of $\rho_{i r}$ as reflecting not just Eastern productivity as such, but also a higher or lower amount of resources necessary to "glue" fragments operated in the East into the respective value-added chain in the West. However, with this reinterpretation of $\rho_{i r}$, the term $\rho_{i r} f_{i r}$ no longer gives the Eastern input requirement for a fragment produced locally in the East; see equation (4). If $\tau_{i r}>1$ denotes the relevant iceberg-type cost parameter, and if these costs are symmetric in either direction, then the requirement of fragment $r$ located in the East per unit of good $i$, provided the companion fragment is also located in the East, is

$$
f_{i r}^{*}=\frac{\rho_{i r}}{\tau_{i r}} f_{i r} .
$$

And if the East sources fragment $r$ in the West, then the per unit requirement is $f_{i r} \tau_{i r}$, if the companion fragment is located in the East. It is obvious that unbundling can now be thought of being triggered by a reduction in $\tau_{i r}$.

As with the narrower interpretation of $\rho_{i r}$ in the previous section, we face the question of whether it is easier to offshore high-skill intensive fragments than low-skill-intensive ones (variation across $r=A, B$ ), and whether offshoring is easier in the more skillintensive of the two industries (variation across $i=1,2$ ). Ideally, one would model the "economics of gluing" explicitly. Doing so in a serious way would very quickly lead to fixed cost elements, thus questioning the iceberg-analogy that I have invoked above. ${ }^{18}$ This is certainly a serious issue, but for the present purpose the iceberg-analogy seems

\footnotetext{
${ }^{18}$ See Baldwin (2006b) and Harris (2001). The literature focusing on the organizational form of international fragmentation typically assumes varying fixed costs of "gluing"; see Antràs \& Helpman (2004). See also Kohler (2001,2004b), where I allow for fixed costs in Ricardo-Viner-type models of offshoring. One could also envisage Heckscher-Ohlin-type stories where gluing is characterized by a certain skill-intensity, related (or not) to the skill-intensity of the fragments glued. Jones (2005) shows that exploiting the cost advantage from international fragmentation subject to a fixed "gluing-cost" leads to a concave minimum cost function.
} 
justified.

A separate issue is how we define the smallest unit where cross-country gluing is possible. Grossman \& Rossi-Hansberg (2006a,b) essentially assume a single input-bundle, but allow for gluing within each type of labor, such that the overall low-skilled labor input may be obtained from domestic or foreign labor markets, and similarly for high-skilled labor. They assume that, within each type of labor, the glue works differently well over a whole range of tasks. Cost-minimization then determines the share of tasks obtained from offshore. High- and low-skilled labor, thus composed in (continuously) variable shares of domestic and foreign workers, are then combined in the usual way according to a standard production function. In a sense, this is the extremest form of unbundling, in Baldwin's (2006b) words: "globalization's finest level of resolution" (p.28). In Kohler (2001,2004b) I have looked at this type of offshoring in a small-country, Ricardo-Viner setup. Grossman \& Rossi-Hansberg (2006b) present a full-fledged Heckscher-Ohlin model with a richer set of results. ${ }^{19}$ In the present paper, unbundling takes place on the lower level of "resolution" that relates to well-defined bundles of high- and low-skilled labor, and not to individual high- or low-skilled workers. Call-centers operating offshore (used to handle customer complaints, say) still need both high- and low-skilled workers, both from the foreign labor market, but in a different proportion from other fragments of the offshoring firm's overall production process. Arguably, this is a somewhat less immediate threat than direct arbitrage on the level of the individual worker. Different technologies (goods) permit different levels of "resolution" in international fragmentation. Ultimately, this is an empirical issue.

Let us begin by returning to the equilibrium with complete bundling. I assume that both countries produce goods 1 and 2 in the initial equilibrium, hence equation (11) plus a corresponding condition for industry 2 must be satisfied. Unbundling now enforces international arbitrage on the level of input-sub-bundles, rather than goods. Thus, producing fragment $r$ of industry $i$ in the West would violate cost-minimization at initial wage rates, if $a_{i r h} w_{h}+a_{i r l} w_{l}>\rho_{i r}\left(a_{i r h} w_{h}^{*}+a_{i r l} w_{l}^{*}\right)$. This is the offshoring perspective from a Western

\footnotetext{
${ }^{19}$ In the Ricardo-Viner model, gluing foreign with home labor is subject to the usual law of diminishing returns. In the Heckscher-Ohlin model of Grossman \& Rossi-Hansberg (2006b), a continuous margin of offshoring arises due to convexity of "gluing-cost" over the range of tasks. In Kohler (2004a), I present a Heckscher-Ohlin model with a continuous margin of offshoring in input-bundles.
} 
point of view. Similarly, producing fragment $r$ of industry $i$ in the East at initial factor prices would violate cost-minimization, if $a_{i r h} w_{h}+a_{i r l} w_{l}<\left[\rho_{i r}\left(a_{i r h} w_{h}^{*}+a_{i r l} w_{l}^{*}\right)\right] / \tau_{i r}$. Obviously, $\tau_{\text {ir }}>1$ opens up a band of arbitrage-free differences in unit-cost between countries. Suppose, for simplicity, that all gluing costs fall to zero, in which case $\tau_{i r}=1$. Then, with (11) satisfied in the initial equilibrium, and with heterogeneous fragments in terms of skill-intensities and Ricardian advantage, an integration production pattern necessarily violates the unbundling-cost-minimization. This is true whatever the detailed pattern of Ricardian advantages $\rho_{i r}$. But the direction of disequilibrium and the subsequent adjustment of production and wages depends on this pattern.

If the Ricardian advantages are neutral throughout, $\rho_{1 A}=\rho_{1 B}=\rho_{1}<1$ and $\rho_{2 A}=$ $\rho_{2 B}=\rho_{2}>1$, then $a_{i r h}^{*} / a_{i l}^{*}=a_{i r h} / a_{i r l}$, and the West has a comparative advantage in the skill-intensive fragments of both, industries 1 and $2 .{ }^{20}$ Conversely for the East. Take good 1 for example. From (11), if the East produces good 2, its Ricardian advantage is strong enough to compensate for the cost-disadvantage deriving from relatively expensive high-skilled labor, given the aggregate skill-intensity of good 1. This then implies that the less skill-intensive of the two fragments must cost less to produce in the East than in the West. Vice versa for the more skill-intensive fragment $A$. The same holds true, a fortiori, if $\rho_{1 B}<\rho_{1}$ (and therefore $\rho_{1 A}>\rho_{1 B}$ from equation 11), i.e., if the Ricardian efficiency gaps are of a reinforcing type. On the other hand, for offsetting Ricardian gaps there exists a critical value $\tilde{\rho}_{1 A}<\rho_{1}$ (with a corresponding value $\tilde{\rho}_{1 B}>\rho_{1}$, again determined by equation 11), such that any $\rho_{1 A}<\tilde{\rho}_{1 A}$ (and $\rho_{1 B}>\tilde{\rho}_{1 B}$ ) confers a comparative advantage to the East (the West) in supplying fragment $A$ (fragment $B$ ) of industry 1 . The same patterns of unbundling obtain for good 2, if the Ricardian efficiency gaps are of the reinforcing or offsetting type there as well. Thus, offsetting Ricardian advantages may give rise to a somewhat counter-intuitive pattern of unbundling, whence the West sources skill-intensive fragments in the East. ${ }^{21}$

In the preceding arguments, I have identified unbundled comparative advantage from the direction in which the cost-minimizing sourcing-condition would be violated, if offshoring did not take place in either direction. This does not yet describe the trading

\footnotetext{
${ }^{20}$ Here $\rho_{1}$ is defined from equation (11), setting $\rho_{1 A}=\rho_{1 B}=\rho_{1}$.

${ }^{21}$ Marin (2004) presents evidence for such skill-intensive German and Austrian offshoring to Eastern Europe.
} 
equilibrium with unbundled comparative advantage. Denoting the equilibrium with unbundling by a tilde $\left(^{\sim}\right)$, the cost-minimization conditions for unbundling may be described as

$$
\begin{array}{llll}
a_{i r h}\left(\tilde{w}_{h}-\rho_{i r}^{*} \tilde{w}_{h}^{*}\right)+a_{1 r l}\left(\tilde{w}_{l}-\rho_{i r} \tilde{w}_{l}^{*}\right) & <0 & \text { iff } & \tilde{g}_{i r}>0 \text { and } \tilde{g}_{i r}^{*}=0, \\
a_{i r h}\left(\tilde{w}_{h}-\rho_{i r}^{*} \tilde{w}_{h}^{*}\right)+a_{1 r l}\left(\tilde{w}_{l}-\rho_{i r} \tilde{w}_{l}^{*}\right)>0 & \text { iff } \quad & \tilde{g}_{i r}^{*}>0 \text { and } \tilde{g}_{i r}=0,
\end{array}
$$

where $\tilde{g}_{i r}$ - defined in (3) above - denotes the equilibrium level of production of fragment $r$ in industry $i$ that takes place in the West, and analogously for $\tilde{g}_{i r}^{*}$ in the East. The inequalities in these expressions describe what I have called margins of international fragmentation in Kohler (2003). They separate fragments produced domestically from those produced offshore. Conditions (13) and (14) might also be called the cost-minimizing "supply-chain-conditions". Given my working hypothesis of incomplete specialization under bundled comparative advantage, and given $\tau_{i r}=1$, equilibrium with unbundling requires that each of the two countries produces only one of the fragments in each of the two industries. In other words, unbundling does take place, its precise pattern depending on the pattern of Ricardian advantages as explained above.

To complete description of the equilibrium, I now define

$$
\begin{aligned}
& \tilde{\pi}_{i A}\left(\tilde{w}_{h}, \tilde{w}_{l}, \tilde{w}_{h}^{*}, \tilde{w}_{l}^{*}\right) \equiv\left[p_{i}-f_{i B}^{*}\left(a_{1 B h} \tilde{w}_{h}^{*}+a_{i B l} \tilde{w}_{l}^{*}\right)\right] / f_{i A}, \\
& \tilde{\pi}_{i B}\left(\tilde{w}_{h}, \tilde{w}_{l}, \tilde{w}_{h}^{*}, \tilde{w}_{l}^{*}\right) \equiv\left[p_{i}-f_{i A}^{*}\left(a_{i A h} \tilde{w}_{h}^{*}+a_{i 1 A l} \tilde{w}_{l}^{*}\right)\right] / f_{i B} .
\end{aligned}
$$

These are the implicit prices of the two fragments in industry $i$, given that they are produced in the West, with the companion fragment produced offshore in the East. In other words, they are imputed prices for home-made fragments, each conditional on offshoring of the other fragment. Analogous definitions hold for fragments produced in the East. Note that (15) and (16) are definitions, not equilibrium conditions.

The cost-minimizing supply-chain-conditions in (10) and (14) do not guarantee zeroprofits for final goods production. Using the definitions in (15) and (16), the zero-profit conditions for a trading equilibrium with unbundled comparative advantage may be written as

$$
\left.\begin{array}{l}
\tilde{\pi}_{i r}\left(\tilde{w}_{h}, \tilde{w}_{l}, \tilde{w}_{h}^{*}, \tilde{w}_{l}^{*}\right)=a_{i r h} \tilde{w}_{h}+a_{i r l} \tilde{w}_{l} \\
\tilde{\pi}_{i r}^{*}\left(\tilde{w}_{h}, \tilde{w}_{l}, \tilde{w}_{h}^{*}, \tilde{w}_{l}^{*}\right)<a_{i r h} \tilde{w}_{h}^{*}+a_{i r l} \tilde{w}_{l}^{*} \\
\tilde{\pi}_{i r}\left(\tilde{w}_{h}, \tilde{w}_{l}, \tilde{w}_{h}^{*}, \tilde{w}_{l}^{*}\right)<a_{i r h} \tilde{w}_{h}+a_{i r l} \tilde{w}_{l} \\
\tilde{\pi}_{i r}^{*}\left(\tilde{w}_{h}, \tilde{w}_{l}, \tilde{w}_{h}^{*}, \tilde{w}_{l}^{*}\right)=a_{i r h} \tilde{w}_{h}^{*}+a_{i r l} \tilde{w}_{l}^{*}
\end{array}\right\} \quad \text { if } \tilde{g}_{i r}>0 \text { and } \tilde{g}_{i r}^{*}=0
$$


where $i=1,2$ and $r=A, B$. In these expressions, $\tilde{g}_{i r}$ and $\tilde{g}_{i r}^{*}$ are determined in line with the cost-minimizing supply-chain-conditions in (10) and (14). Within each industry, the imputed value the domestic fragment, conditional on offshoring the other must be equal to the unit-cost of this fragment. Analogously for fragments produced in the East, with offshoring of the other to the West. $^{22}$ If the domestic unit-cost of any fragment is larger than its implicit price for home production, then it is produced offshore and domestic production of that fragment is zero. Conventional zero-profit conditions hold for industries 0 and 3. General equilibrium is then completed by full employment conditions, if wages are flexible. I assume this to be the case at this stage. The full employment conditions are

$$
a_{0 s} \tilde{y}_{0}+\sum_{i=1,2} \sum_{r=A, B} a_{i r s} \tilde{g}_{i r}+a_{3 s} \tilde{y}_{3}=E_{s} \quad \text { for } s=h, l .
$$

I shall discuss this equilibrium in comparison with the benchmark case of bundled comparative advantage with the aid of figure 2 below.

Ricardian and Heckscher-Ohlin models with more goods than factors exhibit an extreme sensitivity with respect to changes in prices and trade costs. Even small changes can cause extreme shifts in comparative advantage. ${ }^{23}$ In the present context, unbundling may be caused by a small change in real costs of unbundling, but this may result in an extreme shift in the pattern of comparative advantage. This is an uncomfortable feature, but some important insights may still be obtained with the present model, particularly regarding the wage effects of unbundling. ${ }^{24}$ Given the discrete change in the specialization pattern, these cannot be described directly by means of a small-changes-calculus using linear approximations for equilibrium conditions. However, the implicit prices defined above provide a useful vehicle to do something very similar.

\footnotetext{
${ }^{22}$ Of course, if cost-minimization dictates that there be no offshoring, then these imputed values, which are conditional upon offshoring, would be lower than their unit-cost for both fragments. But this case has been ruled out here by assuming incomplete specialization with bundled comparative advantage, coupled with the simplifying assumption that $\tau_{i r}=1$.

${ }^{23}$ In his Graham Lecture at Princeton, Alan Deardorff speaks of hypersensitivity and lists it among 6 uncomfortable features of the Heckscher-Ohlin model; see Deardorff (2006).

${ }^{24} \mathrm{An}$ alternative to the approach pursued here would be to impose conditions that allow one to model offshoring as a movement along a continuous margin, as in Kohler (2004a) and Grossman \& RossiHansberg (2006b).
} 
I focus on wage effects of unbundling in the West. By assumption of incomplete specialization, the initial equilibrium satisfies $\pi_{i r}\left(w_{h}, w_{l}\right)=a_{i r h} w_{h}+a_{i r l} w_{l}$ for $i=1,2$ and $r=A, B$, where the implicit price is as defined in (10) for $i=1$ and $r=B$. Comparing this with the zero-profit conditions (17) and (18), the wage effects from unbundling, $\tilde{w}_{s}-w_{s}$, must satisfy the change from zero-profits with $\pi_{i r}\left(w_{h}, w_{l}\right)=a_{i r h} w_{h}+a_{i r l} w_{l}$ for $i=1,2$ and $r=A, B$ (plus the corresponding conditions for the conventional sectors 0 and 3 ), to conditions (17) and (18). But, starting from a case with incomplete specialization, arbitrary changes $\tilde{\pi}_{i r}\left(\tilde{w}_{h}, \tilde{w}_{l}, \tilde{w}_{h}^{*}, \tilde{w}_{l}^{*}\right)-\pi_{i r}\left(w_{h}, w_{l}\right)$ will typically involve extreme shifts in specialization. Hence, the wage effects cannot be fully described by looking at the zeroprofit conditions alone. The full employment conditions matter as well. I bring them into the picture in figure 2 , where the change from $\pi_{i r}\left(w_{h}, w_{l}\right)$ to $\tilde{\pi}_{i r}\left(\tilde{w}_{h}, \tilde{w}_{l}, \tilde{w}_{h}^{*}, \tilde{w}_{l}^{*}\right)$ is depicted by inward-pointing arrows along factor intensity rays.

Figure 2: Unbundled comparative advantage and factor prices with reinforcing Ricardian efficiency gaps

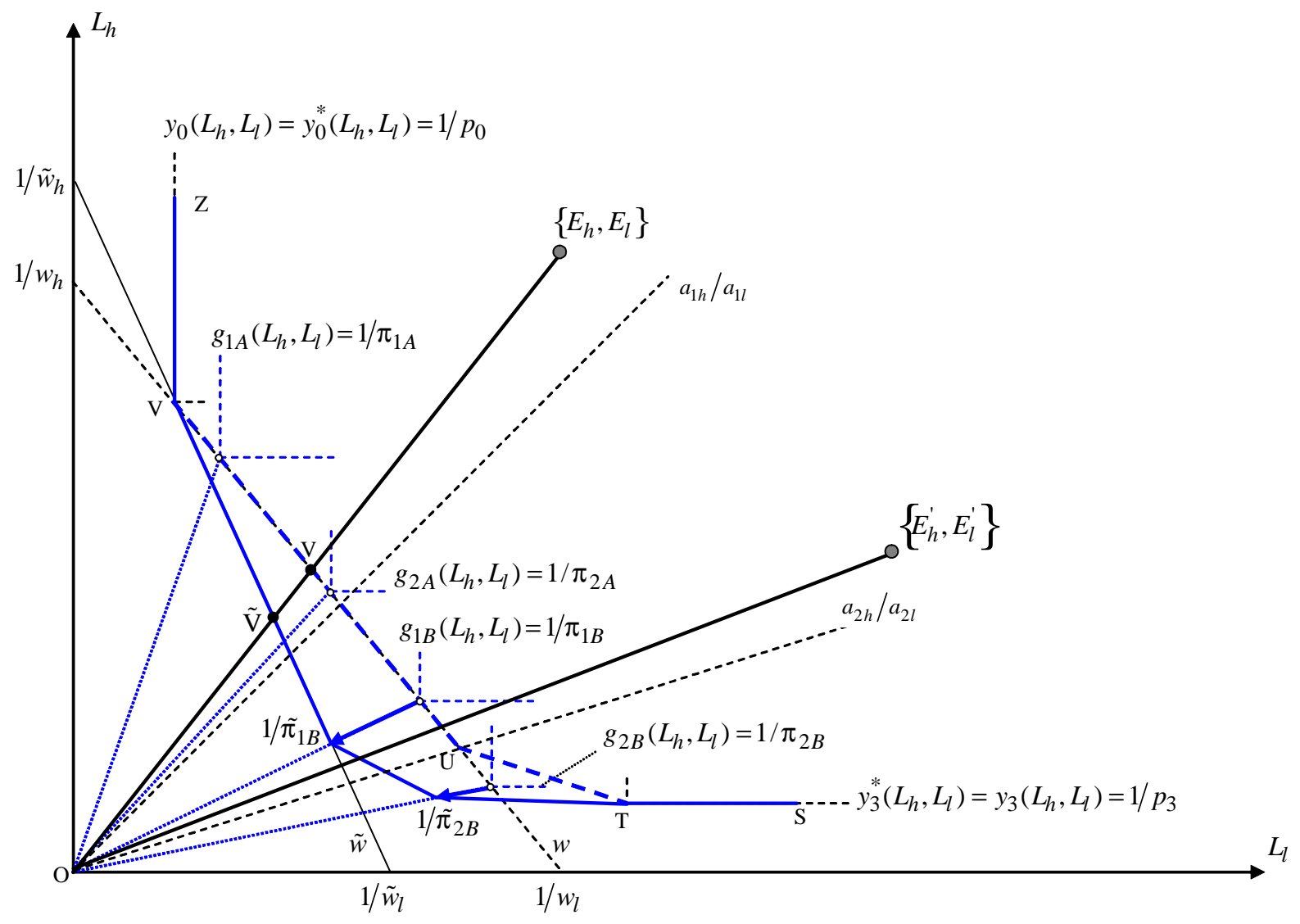


Figure 2 looks at the West and assumes that unbundling moves the source of supply for both of the high-skill intensive fragments to the East. In fact, the West turns out to lose industry 2 entirely. To understand this figure, we first need to describe the changes in imputed prices. It can be shown that the percentage change in the imputed price for fragment $B$ in industry $i$ is equal to ${ }^{25}$

$$
\frac{\tilde{\pi}_{i B}}{\pi_{i B}}-1=\frac{\theta_{i A}}{\theta_{i B}}\left[1-\rho_{i A} \frac{a_{i A h} w_{h}^{*}+a_{i A l} w_{l}^{*}+a_{i A h}\left(\tilde{w}_{h}^{*}-w_{h}^{*}\right)+a_{i A l}\left(\tilde{w}_{l}^{*}-w_{l}^{*}\right)}{a_{i A h} w_{h}+a_{i A l} w_{l}}\right],
$$

where $\theta_{i r}$ is the share of fragment $r$ in the unit-cost of good $i$. Equation (20) represents the cost-saving that industry $i$ firms in the West obtain from relocating production of fragment $A$ to the East, taking into account that unbundling of comparative advantage will also change wage rates in the East from $w_{s}^{*}$ to $\tilde{w}_{s}^{*}$. In $(20)$, these cost-savings are expressed as a percentage increase in the imputed price for fragment $B$, which remains being produced in the West. Given the above assumptions, the bracketed term in (20) is positive, if cost-minimization dictates that fragment $A$ of industry $i$ be sourced in the East. $^{26}$

Grossman \& Rossi-Hansberg (2006b, p.6) state that the productivity effect of offshoring has received relatively little explicit attention in theoretical models of offshoring. Following Kohler (2003), I portray the cost-savings effect of unbundling as changes in the implicit values of certain sub-bundles of labor that are "freed up" from the burden of being bundled with other, less efficient fragments of production. Returning to the notion of "bundling protection", we may interpret the term $\rho_{i A}\left(a_{i A h} w_{h}^{*}+a_{i A l} w_{l}^{*}\right) /\left(a_{i A h} w_{h}+a_{i A l} w_{l}\right)$ appearing in (20) as measuring the amount of protection that fragment $A$ in the West receives from fragment $B$ in the initial equilibrium with bundled comparative advantage. Offshoring fragment $A$ relieves fragment $B$ from this burden. The attendant increase in its implicit value mandates higher wages paid to workers used in fragment $B$ of good $i$ production. The Heckscher-Ohlin aspect of this is given by $\left(a_{i A h} w_{h}^{*}+a_{i A l} w_{l}^{*}\right) /\left(a_{i A h} w_{h}+a_{i A l} w_{l}\right)$,

\footnotetext{
${ }^{25}$ To see this, we first write the percentage change as $\frac{f_{i A}\left(a_{i A h} w_{h}+a_{i A l} w_{l}\right)-f_{i A}^{*}\left(a_{i A h} \tilde{w}_{h}^{*}+a_{i A l} \tilde{w}_{l}^{*}\right) .}{p_{i}-f_{i A}\left(a_{i A h} w_{h}+a_{i A l} w_{l}\right)}$. Zero profits initially implies that the denominator of this expression may be written as $f_{i A}\left(a_{i A h} w_{h}+a_{i A l} w_{l}\right)$. Using $f_{i A}^{*}=\rho_{i A} f_{i A}$, we may therefore write the percentage change as $\frac{f_{i A}\left(a_{i A h} w_{h}+a_{i A l} w_{l}\right)}{f_{i B}\left(a_{i B h} w_{h}+a_{i B l} w_{l}\right)}\left[1-\rho_{i A} \frac{a_{i A h} \tilde{w}_{h}^{*}+a_{i A l} \tilde{w}_{l}^{*}}{a_{i A h} w_{h}+a_{i A l} w_{l}}\right]$. With minor manipulations, we arrive at the expression in the text above.

${ }^{26}$ Strictly speaking, this requires that unbundling of comparative advantage does not reverse the relative factor price ranking between the two countries, which no doubt is a reasonable assumption in the present context.
} 
while the Ricardian efficiency gap appears as $\rho_{i A}$ in (20) above. The term $a_{i A h}\left(\tilde{w}_{h}^{*}-w_{h}^{*}\right)+$ $a_{i A l}\left(\tilde{w}_{l}^{*}-w_{l}^{*}\right)$ measures the extent to which the initial foreign advantage in fragment $A$ is reduced by the foreign wage effects of unbundling, the assumption here being that unbundling leaves the international relative factor price ranking unchanged. The general equilibrium wage effects of any scenario of simultaneous unbundling in many industries is then found by comparing the convex hull determined by prices of bundled activities with the convex hull determined by implicit values of unbundled activities, conditional on offshoring bundles where domestic production suffers from a Heckscher-Ohlin (i.e., factor price) disadvantage in connection with a Ricardian efficiency gap. ${ }^{27}$

Invoking Stolper-Samuelson logic to identify the wage effect from such unbundling, we realize that the crucial question is whether the activity that enjoys an increase in its implicit market value is relatively skill-intensive. But skill-intensive not relative to the activity that is now located offshore, but relative to other activities that remain viable domestically. There may, in general, be many such activities, hence a general result seems hard to derive. However, the domestic skill endowment is a convenient measure of the overall skill-intensity of a country's production. In order to derive general statements, I therefore introduce two definitions regarding the skill-intensity of an industry with respect to a country's endowment and its local comparative advantage. The definitions are introduced for the West, but it is obvious that analogous definitions hold for the East.

Definition 1 (a) I call an industry with a bundled aggregate skill-intensity which is lower than the endowment ratio, $a_{i h} / a_{i l}<E_{h} / E_{l}$, a weak comparative advantage industry. Industries with a higher aggregate skill-intensity are called strong comparative advantage industries.

(b) Industries with unbundled skill-intensities that satisfy $a_{i r h} / a_{i r l}<E_{h} / E_{l}$, for all $r$ are referred to as industries "close to the margin" of local comparative advantage. Industries for which an opposite inequality applies are labelled "distant from the margin" of local comparative advantage.

These definitions only look at the Hechscher-Ohlin element of comparative advantage

\footnotetext{
${ }^{27}$ In the present setup, unbundling takes the form of a discrete change and the productivity effect arises even if we start from zero offshoring. In Grossman \& Rossi-Hansberg (2006b), as in Kohler (2004b), the productivity effect does not arise "at the very beginning" with zero offshoring to start with.
} 
and do not take into account Ricardian efficiency gaps which are equally important in determining a country's output pattern. Part (b), as well as the subsequent propositions, allow for more than just two fragments, although my proof which relies on the LernerPearce diagram takes the case of two fragments, $r=A, B$, whereby within the industry fragment $A$ is always a more skill-intensive fragment than $B$. The two types of industries defined in part (b) need not be exhaustive. We can now state the following proposition regarding wage effects of unbundling of comparative advantage.

Proposition 1 (a) If unbundling takes place only in weak comparative advantage industries, and if unbundling destroys domestic viability of more skill-intensive bundles (type- $A$ fragments), then low-skilled labor gains from unbundling, while high-skilled labor suffers from a lower real wage rate.

(b) If unbundling takes place only in strong comparative advantage industries, and if unbundling destroys domestic viability of less skill-intensive bundles (type-B fragments), then high-skilled labor gains from unbundling, while low-skilled labor loses in terms of a lower real wage rate.

(c) If unbundling takes place only in industries close to the margin of local comparative advantage, then high-skilled labor unambiguously suffers from a real wage reduction, while low-skilled labor gains, irrespective of any detailed structure of unbundling.

(d) If unbundling takes place only in industries that are distant from the margin of local comparative, then high-skilled labor unambiguously gains, while low-skilled labor loses in terms of a lower real wage rate, irrespective of any detailed structure of unbundling.

I prove these statements using the Lerner-Pearce diagram. Figure 2 depicts a case where unbundling takes place in line with part (a) of the proposition. The underlying assumption is that Ricardian efficiency gaps are of a reinforcing type. Remember that reinforcing gaps mean that the skill-abundant West produces both goods with a higher skill-intensity than the East where skills are relatively scarce, because in either industry the West has a Ricardian disadvantage in the more skill-intensive of the two fragments (i.e., fragment $A$ ). Assuming that $\rho_{i A}<\tilde{\rho}_{i A}$ for both $i=1,2$, in both industries the more skill-intensive of the two fragments loses viability in the West. With bundled comparative advantage, there are unit-value isoquants for $g_{i r}$ in either country that lie on the relevant equilibrium segment of the Hicksian convex hull, or on that line extended in a linear fashion, as with $g_{2 B}$ in figure 2 . Their positions are in line with the pre-unbundling 
implicit prices $\pi_{i r}\left(w_{h}, w_{l}\right)$. For instance, the vertex for $g_{1 A}\left(L_{h}, L_{l}\right)=1 / \pi_{1 A}$ is labeled $A_{1}^{\prime}$ in figure 1. Unbundling of comparative advantage moves these unit-value isoquants inward for fragments $B$, in line with the new implicit values $\tilde{\pi}_{i B}\left(\tilde{w}_{h}, \tilde{w}_{l}, \tilde{w}_{h}^{*}, \tilde{w}_{l}^{*}\right)$, depending on the change described in (20). The convex hull now emerges as the line connecting $Z V\left(1 / \tilde{\pi}_{1 B}\right)\left(1 / \tilde{\pi}_{2 B}\right) T S$. The general equilibrium wage rates corresponding to this hull depend on the endowment ratio. Figure 2 depicts an endowment point $\left\{E_{h}, E_{l}\right\}$ in line with part (a) of the above proposition, with the wage rate for skilled labor falling from $w_{h}$ to $\tilde{w}_{h}$, and the wage for low-skilled labor rising from $w_{l}$ to $\tilde{w}_{l}$. This is coupled with an extreme shift in specialization with the only remaining activities of unbundled comparative advantage being industry 0 and fragment $B$ of industry 2 . It is relatively obvious that figure 2 generalizes to the general propositions 1 (a) and (b) above, although the detailed pattern of unbundled comparative advantage may vary.

Propositions 1 (a) and 1 (b) are in line with the intuition underlying the findings of the empirical literature on outsourcing, as mentioned in the introduction. However, that intuition is potentially misleading. To see this, we only need to change the endowment point to $\left\{E_{h}^{\prime}, E_{l}^{\prime}\right\}$, in which case the line segment $\left(1 / \tilde{\pi}_{1 B}\right)\left(1 / \tilde{\pi}_{2 B}\right)$ of the convex hull becomes relevant. Now high-skilled labor gains, while low-skilled labor loses. The crucial point here is that, relative to the earlier case, the economy is much less skill abundant. It cannot find full employment without producing fragment $B$ of industry 2. Although it is still true that the fragments with lower skill-ratios have been "freed-up" from protecting less efficient, high-skill-intensive fragments, among the two freed-up fragments (the less skill-intensive fragments $B$ in both industries), it is the more skill-intensive where the productivity effect is larger, viz. fragment $A$ in industry 1 . Given the less pronounced skill abundance in $\left\{E_{h}^{\prime}, E_{l}^{\prime}\right\}$ relative to $\left\{E_{h}, E_{l}\right\}$, Stolper-Samuelson logic requires that high-skilled labor gains while low-skilled labor loses. The corresponding factor price line is not drawn in figure 2 to avoid clutter. Propositions 1 (c) and (d) include further cases where the simple intuition is misleading, since the wage effects are independent on whether or not unbundling leaves the more skill part(s) of the value added chain viable. It is relatively easy to construct cases where the intuition is supported and cases where it is violated, following the general line of reasoning underlying figure 2 .

It should be instructive to compare proposition 1 with the result obtained by Grossman \& Rossi-Hansberg (2006c), who move to the far extreme of allowing a direct import of lowskill- or high-skill-intensive tasks, respectively, as opposed to offshoring of pre-specified 
bundles composed of both types of workers. This allows them to capture the productivity effect of offshoring in a straightforward and appealing way. To see how, take low-skilled labor. Assuming that some low-skill-type tasks are already obtained from offshore in the initial equilibrium, any reduction in offshoring costs lowers the costs of these inframarginal tasks, and thus the average cost of low-skill-tasks. If this happens symmetrically in two industries with differing average skill-intensities, a reduction of the average cost of low-skill type labor benefits the less skill-intensive industry to a greater extent than the more skill-intensive one. If a full employment equilibrium requires both industries to remain viable, then the only way to restore a zero-profit equilibrium is a rise in the domestic wage rate for low-skilled labor, which restores the initial average cost of lowskill-type tasks. All of the benefit from cheaper offshoring thus accrues to low-skilled labor, even though offshoring affects tasks for low-skilled labor.

In my case, this type of reasoning is not possible, since unbundling always affects subbundles of both types of labor. But the Grossman-Rossi-Hansberg result can be framed in terms of my proposition 1. The cost-savings effect from cheaper foreign low-skilled tasks can equivalently be thought of as an increase in the implicit value of what domestic labor contributes to production value in each of the two industries. If the technology of offshoring is the same for both industries, as assumed by Grossman \& Rossi-Hansberg, then the percentage increase in this implicit value is larger for the industry with the larger ratio of low-skilled to high-skilled workers. In a two-goods-economy, this is like a relative price increase for the less skill-intensive good. Their result then follows from the usual Stolper-Samuelson logic. However, it no longer follows directly, if there are more than two goods. It only follows, if full employment of outputs requires these same two goods to be produced both before and after the change considered. Whether this is the case depends on endowments and factor intensities. And this is why my proposition invokes the full employment conditions through the definitions of weak comparative advantage industries and industries close to the margin, respectively. ${ }^{28}$ The next proposition turns to welfare.

Proposition 2 (a) Under incomplete relative wage convergence, unbundling holds an unambiguous aggregate welfare increase, defined as the possibility to achieve a Pareto

\footnotetext{
${ }^{28}$ See also the related propositions derived in Kohler (2003). The logic is also present in Jones $(2000,2005)$.
} 
improvement via costless lump-sum compensation.

(b) If unbundling takes place in both types of industries, those close to the margin of local comparative advantage as well as those distant from that margin, then unbundling leads to a Pareto-improvement without any compensation requirement, provided the productivity effect (implicit price increase) for the industries affected are not too disproportionate.

This statement is, admittedly, somewhat vague, since it does not specify exactly what is meant by "not too disproportionate". But the proposition nevertheless conveys an interesting and useful general message. Distributional conflicts will typically arise, if unbundling affects activities that are concentrated on one side of the cone of diversification, whereby the line of division is defined by the endowment ratio. In their seminal papers on outsourcing, Feenstra \& Hanson $(1996,1997)$ note the potential for a Pareto improvement of outsourcing low-skill-intensive intermediates. In view of the present analysis, it is crucial that the Feenstra-Hanson-model has only one final goods producing industry. Proposition 2 allows for many sectors, and the case considered in part (b) in some sense mimics a single sector economy. The proof again follows from figure 2. Part a) is seen from the fact that the intersection point between the Hicksian convex hull and the factor endowment ray $E_{h} / E_{l}$ moves closer to the origin. With incomplete convergence, unbundling must lead to "south-west" arrows of the sort depicted in figure 2, located somewhere on the initial hull. So the new hull unambiguously covers new ground further towards the origin, hence the shift in the intersection point on the endowment line. Indeed, the welfare increase may be measured, in terms of labor units, as the distance between points $V$ and $\tilde{V}$. One could also construct the usual Hicksian variation measures. Part (b) follows from the fact that a Pareto-improvement without compensation requirement would only obtain, if the factor price line shifts in such a way that both intersection points with the axes move closer to the origin. Obviously, this requires that the productivity effects as derived in (20) are "not too disproportionate".

\section{Minimum Wages}

The above analysis assumes that unbundling takes place in an ideal environment free of any distortion, policy-induced or otherwise. The real world is less perfect. For instance, the German policy debate about the bazaar-effect revolves around labor market rigidities, 
particularly around the de facto minimum wage rate generated by social security. In this paper, I do not attempt a full-fledged treatment of unbundling under a minimum wage rate. I would also agree that the model of the previous section is not particularly well disposed to analyze the unemployment effects of a minimum wage rate, the reason being that it tends to generate extreme specialization effects, if one retains the assumptions of given world market prices for final goods and Leontief-technologies in all sectors. ${ }^{29}$ For the present purpose, I just accept this type of "hypersensitivity" (Deardorff, 2006) and try do distill a few points from the analysis that I think are interesting and worth making.

Assume, then, that there is a minimum wage for low-skilled labor in the West, $w_{l} \geq$ $w_{l}^{\min }$, and that it is binding in the initial equilibrium with bundled comparative advantage. The amount of unemployment can be found by rotating the factor price line with a fixed intersection point $w_{l}^{\min }$ on the horizontal axis, such that it becomes tangent to the convex hull of unit-value isoquants. Except for an unlikely coincidence tangency will arise at a kink of the convex hull which gives the skill-intensity of the industry (industries) that are viable in the West, given world market prices and the minimum wage rate. Denoting this skill-intensity by $\alpha$, employment of low-skilled labor is equal to $E_{h} / \alpha$, and the rate of unemployment of low-skilled labor is equal to $1-\left(E_{h} / E_{l}\right) / \alpha$. This equates the high-skilled and low-skilled labor endowment with the number of people with respective skills, assuming an exogenous unitary labor supply per person. A binding minimum wage implies that $\alpha>E_{h} / E_{l}$. Normalizing the overall population to 1 , the overall rate of unemployment is equal to $\left(\alpha-E_{h} / E_{l}\right) / \alpha$. Figure 3 depicts a case with 6 kinks corresponding to 6 final goods, the convex hull running from $U$ to $Z$.

In figure 3, the implicit zero-profit fragments of the two component bundles that lie behind the aggregate skill-intensity $\alpha$ are given by points $A^{\prime}$ and $B^{\prime}$. This is in perfect analogy to figure 1 above. I now assume, arbitrarily, that unbundling of comparative advantage "frees up" the less skill-intensive, but more productive fragment $B$. This corresponds to the case with reinforcing Ricardian advantage of figure 2 . The productivity effect is depicted by the arrow between points $B^{\prime}$ and $\tilde{B}^{\prime}$, and the convex hull now emerges as $U V Z$. With flexible wages, we would observe a reduction in the wage for high-skilled

\footnotetext{
${ }^{29}$ Egger \& Kreickemeier (2005) discuss outsourcing in a model where unemployment arises from a fair wage restriction.
} 
labor and a rise in the wage for low-skilled labor, in line with proposition 1 (a) above. ${ }^{30}$ Also, proposition 2 would imply that such a pattern of unbundling is no Pareto improvement. With the minimum wage rate, we observe a reduction of unemployment, in line with the skill-intensity of fragment $B$, denoted by $\tilde{\alpha}_{B}$, coupled with a rise in the wage rate for high-skilled labor, from $w_{h}$ to $\tilde{w}_{h}$ as depicted. This is a clear Pareto improvement. A second point worth stressing at this stage is that the magnitude of the productivity effect from unbundling is irrelevant for the employment effect, which is determined solely by the skill-intensity $\tilde{\alpha}_{B}$. Variations in the magnitude of the productivity effect are entirely absorbed by larger or smaller increases in the wage for high-skilled labor.

Figure 3: Unbundling comparative advantage with a minimum wage rate

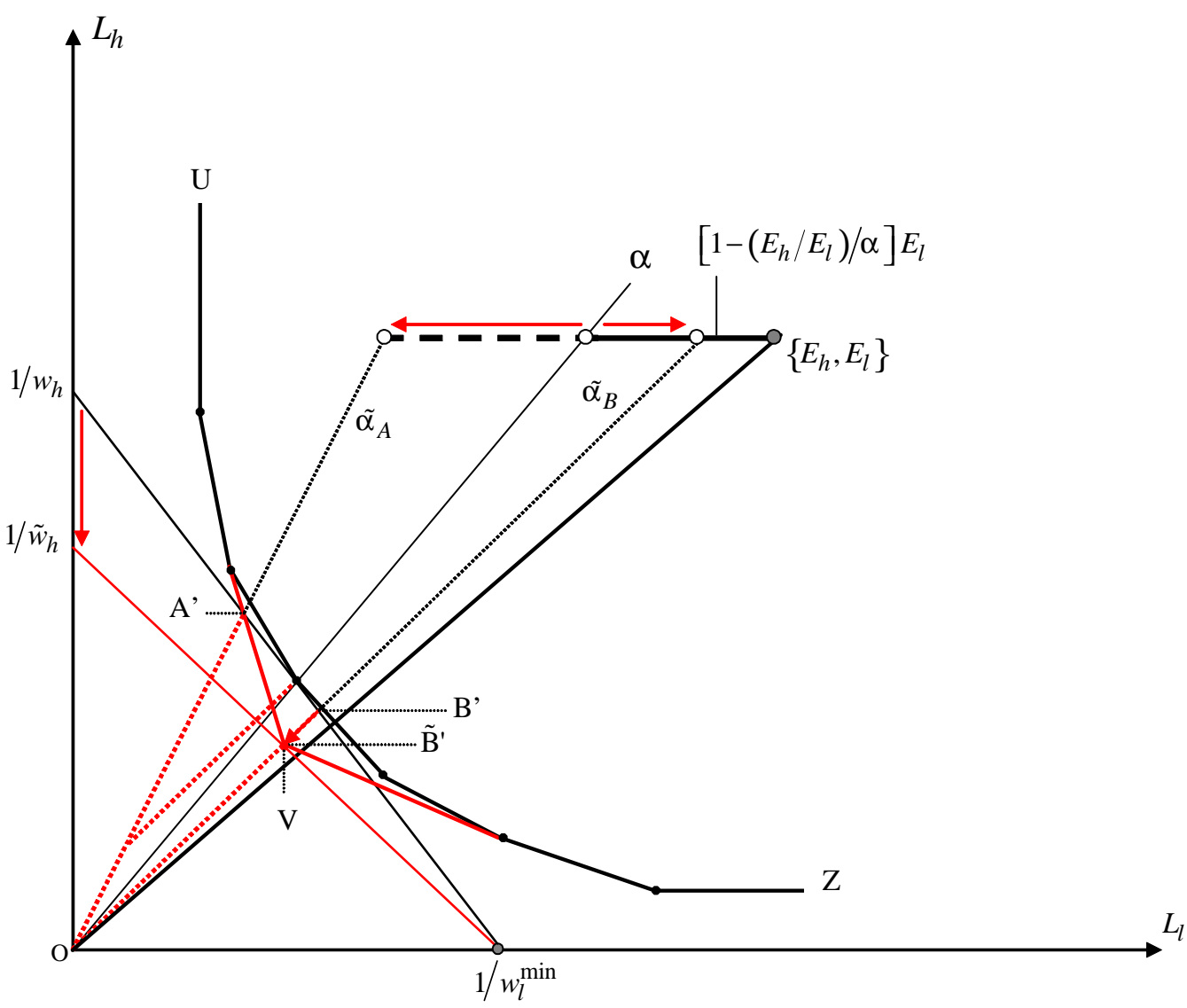

\footnotetext{
${ }^{30}$ In that proposition the endowment ratio would now need to be replaced by the employed endowment ratio.
} 
The crucial condition behind the results identified in the preceding paragraph is that $\alpha>\tilde{\alpha}_{B}>E_{h} / E_{l}$, whereby $\alpha$ is determined by the minimum wage rate, in connection with the country's technology and given world prices. If we view the high-skilled wage effect as a function of $\tilde{\alpha}_{B}$, other things equal (such as the magnitude of the productivity effect, measured by the length of the arrow from $B^{\prime}$ to $\tilde{B}^{\prime}$ ), then the skilled wage increase becomes ever larger as $\tilde{\alpha}_{B}$ becomes smaller, as long as $\tilde{\alpha}_{B}$ remains in the aforementioned interval. However, once $\tilde{\alpha}_{B}$ reaches $E_{h} / E_{l}$, the minimum wage rate is no longer binding, and at this stage there is a discontinuity in the wage adjustment. For $\tilde{\alpha}_{B}$ values below $E_{h} / E_{l}$, the logic of proposition 1 (a) above applies in full force and skilled labor loses, however tiny the productivity effect. No such discontinuity arises if unbundling leaves fragment $A$ viable. Again the unemployment effect is determined from the corresponding skill-intensity $\tilde{\alpha}_{A}$ alone, as indicated in figure 3 . And skilled labor unambiguously gains, whatever the value of $\tilde{\alpha}_{A}$. The wage effect for skilled labor, though positive for all values of $\tilde{\alpha}_{A}$ (whereby $\tilde{\alpha}_{A}>\alpha$ by definition of fragment $A$ ), is falling in $\tilde{\alpha}_{A}$. The intuition for this is that, with a binding minimum low-skill wage rate $w_{l}^{\min }$, a given productivity effect on fragment $A$ from offshore procurement of fragment $B$ mandates a wage increase which is the higher, the lower $a_{i A h}$. From $\pi_{i A}=a_{i A h} w_{h}+a_{i A l} w_{l}$, setting $w_{l}=w_{l}^{\text {min }}$, we have $\mathrm{d} w_{h}=\left(1 / a_{i A h}\right) \mathrm{d} \pi_{i A}$, where $\mathrm{d} \pi_{i A}$ represents the implicit price increase for fragment $A$. Along the factor price line for the bundled comparative advantage equilibrium, $a_{i A h}$ increases as $\tilde{\alpha}_{A}$ becomes larger. This same logic also explains why in the earlier scenario the wage effect for high-skilled labor increases, other things equal, as $\tilde{\alpha}_{B}$ falls from $\alpha$ down to $E_{h} / E_{l}$. We may summarize all of this in the following proposition.

Proposition 3 If the initial equilibrium with bundled comparative advantage features a binding minimum wage for low-skilled labor in the West, with unemployment of low-skilled labor equal to $\left[1-\left(E_{h} / E_{l}\right) / \alpha\right] E_{l}$, then unbundling of comparative advantage has the following effects on unemployment and the wage for high-skilled labor:

(a) If unbundling leaves viable fragments with a skill-intensity $\tilde{\alpha}$ lower than $\alpha$ but higher than $E_{h} / E_{l}$, then unemployment falls and the wage of high-skilled labor rises. The unemployment effect is determined solely by $\tilde{\alpha}$, while the wage effect is determined only by the productivity effect of offshoring.

(b) If unbundling leaves viable fragments with a skill-intensity $\tilde{\alpha}$ lower than $E_{h} / E_{l}$, then the minimum wage rate is no longer binding, unemployment disappears, and high-skilled labor loses. At the point $\tilde{\alpha}=E_{h} / E_{l}$ the wage effect for high-skilled labor jumps from 
positive to negative (discontinuity).

(c) If unbundling leaves viable fragments with a skill-intensity $\tilde{\alpha}>\alpha$, then unemployment rises, with an attendant rise in the wage for skilled labor. The unemployment effect is determined by $\tilde{\alpha}$ alone. The wage effect depends on the productivity from offshoring, and - other things equal - it is falling in $\tilde{\alpha}$.

\section{$5 \quad$ Unbundling and Trade Policy}

Unbundling of comparative advantage may obviously lead to bazaar effects. The German debate revolving around the bazaar-effect sometimes seems to take it for granted that an industry experiencing a bazaar-effect also undergoes a contraction. Bazaar-effects are seen as early signs of a loss of international competitiveness and a long-run decline of the industries affected. This must be questioned on two accounts.

First, on a fundamental level, unbundling questions the very notion of countries hosting entire industries. In a broader context, conditions like (13) and (14) dictate costminimizing supply chains, potentially spanning a large set of locations or countries, and unbundling renders the notion of entire industries that are located in single countries outdated. The analysis in this paper suggests that the appropriate view of an industry is that of a cost-minimizing supply chain. But what, then, does it mean for a country to own or host such a supply chain? This is an interesting and important question, but I do not pursue it any further in this paper. There are also far reaching implications for the appropriate approach that countries should pursue towards drawing up useful and informative foreign trade statistics. Indeed, a large part of existing statistics may have lost, and probably will further lose, their usefulness due to the type of unbundling portrayed in this paper, at least as long as trade is recorded on the basis of output value, not value added. $^{31}$

Perhaps more worryingly, unbundling may already have rendered industrial or commodity classifications that have shaped existing trade policy obsolete. Yet, the tariff schedules based on these classifications remain in place while unbundling unfolds. This has two important consequences. First, unbundling aggravates the "spaghetti bowl" syn-

\footnotetext{
${ }^{31}$ See the study commissioned by the US National Research Council (2006).
} 
drome of regional trading arrangements, first pointed out by Bhagwati et al. (1998). Such arrangements usually involve rules of origin which are, in turn, based on some form of content rule. But with potentially complex supply chains, implementing such rules becomes very expensive, and they are liable to become instruments of costly protection. Even without such abuse, existing rules may become forceful barriers for efficient supply chains that would otherwise emerge from unbundling of comparative advantage. As a result, the cost of protection, relative to free trade, is likely to increase.

The second implication is more general in that it does not relate to preferential trading arrangements. Suppose there are pre-existing tariffs on several goods. The theory of effective protection suggests that unbundling of comparative advantage changes their protective effect. The attendant reallocation effects are notoriously difficult to predict, if there are many sectors that are affected. But the above analysis reveals that the direct reallocation effect need not be in line with the intuition that industries with bazaar-effects are likely to also contract in terms of employment. This is almost trivial for the general case were there are more activities than factors, where production is indeterminate. I therefore look at a case where the structure of production is uniquely determined.

Suppose there are only two industries, say industries 0 and 2 in figure 2 above. Given the unit-value isoquants and equilibrium factor prices, the usual Rybczynski-type diagram tells us the equilibrium allocation of high-skilled and low-skilled labor among the two industries. If offshoring is restricted to industry 2, as assumed above, then there will be reallocation of both types of labor from industry 0 into industry 2 , provided that unbundling makes industry 2 more skill-intensive, i.e. if the more skill-intensive fragment $A$ remains viable. This can only be an equilibrium if fragment $A^{\prime}$ s skill-intensity is lower than $E_{h} / E_{l}$, but for the present purpose we may assume this to be the case. The bazaareffect is thus coupled with an expansion, not a contraction of the industry. The opposite holds for a reverse unbundling pattern.

Reallocation effects of this sort may be important in their own right, but they gain added importance, if there are pre-existing trade distortions, like import tariffs or export subsidies. It is well known that aggregate welfare of a country increases if imports of a good which is subject to a tariff increase. Any exogenous change that leads to such an 
increase has a positive first-order aggregate welfare effect. ${ }^{32}$ In the simple case discussed in the preceding paragraph, if good 2 is imported and if there is an import tariff, then the bazaar-effect involves a negative first-order welfare effect on account of the pre-existing distortion. The reason is that it enhances domestic output of industry 2. Under plausible conditions, this lowers imports of good 2, which are suboptimally low to start with (due to the import tariff). This undermines the positive welfare effect from offshoring identified in proposition 2 above. If good 2 is an export good, then the same pattern of unbundling involves a positive first-order welfare effect. Thus, if exports of a certain industry increase although bazaar-type phenomena reduce its domestic production depth, this may well be beneficial. All of these conclusions are, of course, reversed if the pattern of unbundling leads to a reverse reallocation pattern (expansion of industry 0). To the best of my knowledge, such first-order welfare effects of offshoring that follow from pre-existing tariffs have so far not been noticed in the offshoring literature. In my view they merit further attention.

\section{Offshoring versus Migration}

Although the cost of migration has fallen over the past two decades, the reduction in the costs of offshoring has no doubt been even larger. Better "glues" have been developed for "gluing" productive services generated abroad into domestic value added chains. Political apprehension is observed with respect to both, offshoring and migration, perhaps resting on the belief that they have similar effects on wages and employment opportunities for domestic workers in countries where offshoring takes place, and in countries receiving inward labor migration, respectively. This seems most likely for the type of "high-resolutionoffshoring" analyzed by Grossman \& Rossi-Hansberg (2006b), where low-skilled labor is "glued" directly into domestic production. Indeed, this type of offshoring might even involve some "migration" in the form of domestic high-skilled labor moving abroad in order to combine with foreign low-skilled labor, say in line with the requirement of a certain inputs sub-bundle in the sense described above.

\footnotetext{
${ }^{32}$ See, for instance, Anderson \& Neary $(2005$, ch. 3) for a general treatment. It is relatively obvious that the reasoning applies not just to reallocation of resources used for final goods, but also for inputsub-bundles of the type analyzed above.
} 
But this would not constitute migration in the usual sense of the word, because highskilled labor would not enter the foreign pool of high-skilled labor, earning the ongoing foreign wage $w_{h}^{*}$. Instead, it would perform specific tasks related to a productive service for a certain domestic industry, and earning the domestic wage rate $w_{h}$ although working abroad. Alternatively, such trade in tasks might also take place through "onshoring" foreign labor, but paying it the foreign wage rate, gross of any cost of movement born by the worker. ${ }^{33}$ In some models of offshoring where this cost is convex in the amount of foreign labor used, as in Grossman \& Rossi-Hansberg (2006b), the equilibrium wage paid to foreign low-skilled labor is equal to the domestic wage rate, adjusted for the cost of offshoring (or "onshoring", for that matter) at the margin. If the cost of offshoring is the same as the cost of migrating, and if one assumes the same condition to govern offshoring in all industries, then immigration and offshoring lead to the same amount of low-skilled foreign labor used in domestic production.

But, as noted by Grossman \& Rossi-Hansberg (2006b), the gains involved in migration and offshoring, respectively, accrue to different people. The easiest case to look at is one where both economies exhibit factor price insensitivity. Technically, this implies that the factor endowment ray intersects the convex hull of unit-value isoquants in the interior of one of its linear segments. If low-skilled labor in the East has a marginal value productivity equal to $w_{l}^{*}<w_{l}$, then labor reallocation from East to West obviously generates an efficiency gain. But who will reap this gain? With offshoring, convex offshoring costs lead to a downward-sloping demand by Western firms for Eastern low-skilled labor, meeting a flat Eastern supply. With migration, costs of migration lead to an upward-sloping supply of Eastern low-skilled migrants meeting flat Western demand for low-skilled labor. Obviously, the incidence of benefits will be different. With offshoring, gains accrue to Western firms and, ultimately, their workers. With migration, these same gains are enjoyed by Eastern migrants.

There is a further key difference between migration and offshoring. With migration,

\footnotetext{
${ }^{33}$ This form of globalization bears a close resemblance to certain modes of trade in services under the GATS; see Bhagwati et al. (2005). It is also highly relevant against the backdrop of the heated debate about the Directive on Services in the Internal Market of the EU. The original intention was to implement the origin principle, according to which labor services could be provided "onshore" in country $A$ by workers from country $B$, under laws and regulation existing in country $B$.
} 
foreign labor enters the entire domestic pool of labor, say of the low-skill type. With offshoring, labor enters the domestic economy in a much more selective way, since it will not normally be feasible equally well across all industries. If industries differ in their skill-intensity, this matters a lot for the wage effect, as we have seen above. There will be potentially severe wage effects from offshoring even in situations where the economy as a whole would exhibit factor price insensitivity to immigration. To see this, take figure 1 above and change shift the endowment point to the right while leaving the unit-value isoquants, and thus the convex hull, unchanged. There is no wage effect, at least for a moderate change. By way of contrast, any pattern of offshoring will change the convex hull, as we have seen in detail above.

The truly fundamental difference between the two forms of globalization, however, is that offshoring allows the domestic economy to resort to foreign supply of labor at foreign conditions (wages), while migration allows foreign workers to enter domestic value added chains at domestic conditions (wages). This is reminiscent of Ramaswami's (1968) result on the optimal policy for factor flows, which was much discussed in the 1980s, particularly with respect to migration (see Bhagwati \& Srinivasan, 1983), but has since fallen into oblivion. A key ingredient of the optimal policy identified by Ramaswami is to employ foreign labor (as migrants) in domestic production at a (net-of-tax) wage which is equal to the foreign rate, and which is therefore lower than the wage for native labor with the same production characteristics. This type of discrimination was, and still is, widely regarded as unacceptable. But it is evident from the above that offshoring involves just this type of discriminatory use of foreign labor, except that in the context of offshoring the foreign labor employed is not migrants, but workers employed in their home country. Thus, the issue of discrimination simply does not arise, at least not in a directly obvious way. ${ }^{34}$

Are we to conclude, then, that offshoring is a deplorable attempt to achieve what in reaction to the Ramaswami theorem was widely considered unacceptable - a "Ramaswamitype policy" in disguise? In my view, this conclusion would be wrongheaded. If international earnings discrepancies are any indication of differing marginal value productivities of labor, then international reallocation of labor holds enormous efficiency gains for the

\footnotetext{
${ }^{34}$ See the discussion in Jones (2005).
} 
world economy. Aiming for a reallocation where most of these gains end up in rich countries' pockets would certainly be deplorable. But offshoring does not do this in a systematic way. True, labor migration would probably be the straightest way to reduce international inequality. It may, however, be coupled with unwelcome redistribution in receiving countries. For this and other reasons, labor migration faces severe political obstacles in potential receiving countries. Restrictions on immigration are widely regarded as an accepted exercise of national sovereignty towards protection of native workers. As Freeman (2006) notes, one way forward would be to "redistribute the benefits of immigration so that a greater share of the benefits flow to natives and a lower share to the benefits to immigrants". Given the aforementioned difference regarding the incidence of efficiency gains from offshoring and migration, respectively, offshoring might be a useful element in a general strategy to achieve efficiency gains from reallocation of labor through forms of globalization that are politically feasible.

The usefulness of offshoring for such a strategy derives from the foreign factor price effects that have been shut off, for simplicity only, in my previous argument. One way to think of this issue is to see a trade-off between the efficiency gain achieved through reallocating the world's labor from low to high marginal productivity uses on the one hand, and unwelcome labor market consequences (wages, employment) in high income countries. Political preferences, mainly in advanced countries, determine a politically optimal position on this trade-off. The above analysis suggests that this trade-off may be quite different in a case where efficiency gains are obtained through migration from low income to high income countries from a case where such gains are sought through offshoring bits and pieces of high income countries's production to low wage countries. Moreover, the analysis suggests that, all discomposure about offshoring notwithstanding, the political equilibrium allows for a larger efficiency gain to be achieved via offshoring than via migration. ${ }^{35}$ The snag is that with offshoring a larger share of the gain is likely to end up in high income countries. But even so, low income countries may still be better off this way than with the much lower overall efficiency gain that is feasible via migration alone.

\footnotetext{
${ }^{35} \mathrm{~A}$ further point to be taken into account here is the apparent low responsiveness of international migration with respect to international income and wage differences.
} 


\section{Summary and Conclusion}

From a narrow perspective of a single industry, offshoring may sometimes look like losing certain stages of production that have traditionally been viewed as pivotal to the industry's international competitiveness. If this happens in several industries, one may be tempted to see the specter of de-industrialization, or a move from an industrial stronghold to a bazaar economy. In this paper, I have suggested a somewhat broader interpretation of events. Bazaar-effects may reflect grand-scale unbundling of comparative advantage, leading to a whole new pattern of specialization that negates traditional views according to which countries host whole industries. If viewed in this way, certain bazaar-type phenomena are far less worrying than some of the rhetoric used in recent debates might suggest.

I have described this type of unbundling by using a stylized model that features Ricardian plus Heckscher-Ohlin mechanisms of comparative advantage. For many goods, modern industrial production must be seen as involving several fragments, or sub-bundles of inputs. A country's comparative advantage may be particularly strong for some subbundles, while for others it may actually have a comparative disadvantage. If the process cannot be unbundled, only average advantage matters. If advances in technology and institutions allow for unbundling of such fragments across borders, then the international structure of production may undergo far-reaching changes.

Within each economy, this change has two important dimensions that determine how it affects individual workers and the overall well-being of the economy. First it involves a whole new pattern of domestic demand for different types of labor (or more generally different types of factors). And secondly, it allows countries to reap productivity gains by "freeing up" certain fragments of production chains from being bundled with less efficient ones. The net effect of both types of changes on earnings and employment perspectives of different types of workers depends on the detailed pattern of unbundling. As a general statement, this is no surprise. What I have done in this paper is to describe the characteristics of such unbundling that are relevant for whether it is low-skilled or high-skilled labor that stands to gain or lose in terms of real wage income.

An important message from the analysis is that some of the intuition that one finds invoked in the public debate as well as in the empirical literature, while probably correct for the short run, is wrongheaded in the long run. In particular, offshoring of inputsub-bundles that intensively use low-skilled labor may well benefit domestic low-skilled 
workers. Indeed unbundling may even be Pareto-improving. While such possibilities have been recognized in the past, the challenge was to identify in a useful way the general mechanism that drives such counter-intuitive possibilities.

The results presented here leave much room for further work. I see at least two potentially fruitful avenues. First, empirical work that tries to identify the direction and magnitude of wage effects from offshoring should explicitly differentiate between shortrun and long-run effects. And in doing so, it should allow for non-monotonic adjustment. My results do not, of course, go as far as suggesting how such a dynamic specification should look like, but the potential for non-monotonicity is there. And my results should go some way at least towards identifying observable variables that need to be taken into account towards richer dynamic specifications. And secondly, from a theoretical perspective, knowing the characteristics of industries and fragments that determine whether wage effects from offshoring favor one type of labor over another is only half the story. To complete the story one needs to explore the relationship between these characteristics on the one hand and the elements that drive offshoring on the other. These latter elements have to do with the "economics of gluing" fragments of production that are separated, not only in space as such, but also across countries and jurisdictions. In other words, what we need is merging the two strands of literature that I have identified above, one focusing (like this paper) on the general equilibrium wage and employment effects, the other focusing on costs of communication, transport and contractual imperfections. This should also generate further insight into whether offshoring is indeed a useful alternative to migration for reducing worldwide inequality, as I have suggested in this paper. 


\section{References}

[1] Anderson, James E. and J. Peter Neary (2005), Measuring the Restrictiveness of International Trade Policy, Cambridge, Mass.: MIT Press.

[2] Antràs, Pol and Elhanan Helpman (2004), Global Sourcing, Journal of Political Economy 112, 552-580.

[3] Antràs, Pol and Elhanan Helpman (2006), Contractual Frictions and Global Sourcing, mimeo, Harvard University, Department of Economics.

[4] Amiti, Mary and Shang-Jin Wei (2005a), Fear of Service Outsourcing: Is It Justified? Economic Policy 20, 307-347.

[5] Amiti, Mary and Shang-Jin Wei (2005b), Service Offshoring, Productivity, and Employment: Evidence from the United States, IMF Working Paper 5/238.

[6] Baldwin, Richard (2006a), Europe's reaction to the challenge of globalization, CESifo Forum, vol. 7, 29-35.

[7] Baldwin, Richard (2006b), Globalization: the great unbundling(s), prepared for the Finnish Prime Minister's Office, Economic Council of Finland, (in context of EU Presidency 2006).

[8] Bhagwati, Jagdish, David Greenaway and Arvind Panagariya (1998), Trading Preferentially: Theory and Policy, The Economic Journal 108, 1128-148.

[9] Bhagwati, Jagdish, Arvind Panagariya and T.N. Srinivasan (2005), The Muddles over Outsourcing. Journal of Economic Perspectives 18, 93-114.

[10] Bhagwati, Jagdish and T.N. Srinivasan (1983), On the choice between capital and labor mobility, Journal of International Economics 14, 209-221.

[11] Deardorff, Alan V. (1979), Weak links in the chain of comparative advantage, Journal of International Economics 9, 197-209.

[12] Deardorff, Alan V. (2001a), Fragmentation in Simple Trade Models, North American Journal of Economics and Finance 12, 121-137. 
[13] Deardorff, Alan V. (2001b), Fragmentation across cones, in: Sven W. Arndt and Henryk Kierzkowski (eds.), Fragmentation: New Production Patterns in the World Economy, Oxford: Oxford University Press.

[14] Deardorff, Alan V. (2004), Local Comparative Advantage: Trade Costs and the Pattern of Trade, Gerald R. Ford School of Public Policy, The University of Michigan, Ann Arbor, Research Seminar in International Economics, Discussion Paper No. 500.

[15] Deardorff, Alan V. (2005a), A trade theorist's take on skilled-labor outsourcing, International Review of Economics and Finance 14, 259-271.

[16] Deardorff, Alan V. (2005b), Ricardian Comparative Advantage with Intermediate Inputs, The North American Journal of Economics and Finance 16, 11-34.

[17] Deardorff, Alan V. (2006), Needs and Means for a Better Workhorse Trade Model, Princeton University, Princeton Graham Memorial Lecture 2006.

[18] Egger, Hartmut and Udo Kreickemeier (2005), International Fragmentation: Boon or Bane for Domestic Employment?, University of Nottingham Working Paper, April 2005.

[19] Ethier, Wilfred J. (1977), The Theory of Effective Protection in General Equilibrium: Effective-Rate Analogues to Nominal Rates, Canadian Journal of Economics $10,233-245$.

[20] Feenstra, Robert C. and Gordon H. Hanson (1996), Foreign investment, outsourcing and relative wages, in: Robert C. Feenstra, Gene Grossman and Douglas A. Irwin (eds.), Political Economy of Trade Policy: Papers in Honor of Jagdish Bhagwati, Cambridge, Mass.: MIT Press.

[21] Feenstra, Robert C. and Gordon H. Hanson (1997), Foreign direct investment and relative wages: evidence from Mexico's Maquiladoras, Journal of International Economics 42, 371-93.

[22] Feenstra, Robert C. and Gordon H. Hanson (2004), Global production sharing and rising inequality: a survey of trade and wages, in: E. Kwan Choi and James Harrigan (eds.), Handbook of International Trade, Oxford: Blackwell Publishing, ch.6. 
[23] Freeman, Richard B. (2006), People Flows in Globalization, Journal of Economic Perspectives 20, 145-170.

[24] Görg, Holger and Sourafel Girma (2004), Outsourcing, Foreign Ownership and Productivity: Evidence from UK Establishment Level Data, Review of International Economics 12, 817-832.

[25] Görg, Holger and Aoife Hanley (2005), Labour demand effects of international outsourcing: Evidence from plant-level data, International Review of Economics and Finance 14, 365-376.

[26] Grossman, Gene M. and Elhanan Helpman (2005), Outsourcing in a Global Economy, Review of Economic Studies 72, 135-159.

[27] Grossman, Gene M. and Esteban Rossi-Hansberg (2006a), The Rise of Offshoring: It's not Wine for Cloth Anymore, Presented at the Federal Reserve Bank of Kansas City Economic Symposium "The New Economic Geography: Effects and Policy Implications", Jackson Hole, Wyoming, August 24-26, 2006.

[28] Grossman, Gene M. and Esteban Rossi-Hansberg (2006b), Trading Tasks: A Simple Theory of Offshoring, Mimeo, Princeton, N.J.: Princeton University.

[29] Harris, Richard (2001), A Communication Based Model of Global Production Fragmentation, in: Sven W. Arndt and Henryk Kierzkowski (eds.), Fragmentation: New Production Patterns in the World Economy, Oxford: Oxford University Press.

[30] Helpman, Elhanan (2006), Trade, FDI, and the Organization of Firms, Cambridge, Mass.: NBER Working Paper 12091, March 2006.

[31] Jones, Ronald W. (2000), Globalization and the Theory of Input Trade, Cambridge, Mass.: MIT Press.

[32] Jones, Ronald W. (2005), Immigration vs. outsourcing: Effects on labor markets. International Review of Economics and Finance 14, 105-114.

[33] Jones, Ronald W. and Henryk Kierzkowski (1990), The role of services in production and international trade: a theoretical framework, in: Ronald W. Jones and Anne O. Krueger (eds.), The Political Economy of International Trade, Oxford: Basil Blackwell. 
[34] Jones, Ronald W. and Henryk Kierzkowski (2000), Globalization and the Consequences of International Fragmentation, in: Rudiger Dornbusch, Guillermo Calvo and Maurice Obstfeld (eds.), Money, Factor Mobility, and Trade: Festschrift in Honor of Robert A. Mundell, Cambridge, Mass.: MIT Press.

[35] Kohler, Wilhelm (2001), A specific-factors view on outsourcing, North American Journal of Economics and Finance 12, 31-53.

[36] Kohler, Wilhelm (2003), The Distributional Effects of International Fragmentation, German Economic Review 4, 89-120.

[37] Kohler, Wilhelm (2004a), Aspects of International Fragmentation, Review of International Economics 12, 793-816.

[38] Kohler, Wilhelm (2004b), International Outsourcing and Factor Prices with Multistage Production, Economic Journal 114, C166-C185.

[39] Marin, Dalia (2004), A Nation of Poets and Thinkers - Less So with Eastern Enlargement? Austria and Germany, London: CEPR Discussion Paper No. 3526.

[40] Markusen, James R. (1983), Factor Movements and Commodity Trade as Complements, Journal of International Economics 14, 341-356.

[41] National Research Council (2006), Analyzing the U.S. Content of Imports and the Foreign Content of Exports, Washington, D.C.: The National Academies Press.

[42] Ramaswami, V.K. (1968), International Factor Movement and the National Advantage. Economica 35, 309-310.

[43] Sinn, Hans W. (2005a), Hans-Werner Sinn, Die Basar-Ökonomie. Deutschland: Exportweltmeister oder Schlusslicht?, München: Econ-Verlag.

[44] Sinn, Hans W. (2005b), Basar-Ökonomie Deutschland: Exportweltmeister oder Schlusslicht?, Ifo Schnelldienst, Jg. 58. 


\section{CESifo Working Paper Series}

(for full list see www.cesifo-group.de)

1872 Hans Gersbach and Bernhard Pachl, Cake Division by Majority Decision, December 2006

1873 Gunther Schnabl, The Evolution of the East Asian Currency Baskets - Still Undisclosed and Changing, December 2006

1874 Horst Raff and Michael J. Ryan, Firm-Specific Characteristics and the Timing of Foreign Direct Investment Projects, December 2006

1875 Jukka Pirttilä and Håkan Selin, How Successful is the Dual Income Tax? Evidence from the Finnish Tax Reform of 1993, December 2006

1876 Agnieszka Stążka, Sources of Real Exchange Rate Fluctuations in Central and Eastern Europe - Temporary or Permanent?, December 2006

1877 Xavier Calsamiglia, Teresa Garcia-Milà and Therese J. McGuire, Why do Differences in the Degree of Fiscal Decentralization Endure?, December 2006

1878 Natacha Gilson, How to be Well Shod to Absorb Shocks? Shock Synchronization and Joining the Euro Zone, December 2006

1879 Scott Alan Carson, Modern Health Standards for Peoples of the Past: Biological Conditions by Race in the American South, 1873 - 1919, December 2006

1880 Peter Huber, Michael Pfaffermayr and Yvonne Wolfmayr, Are there Border Effects in the EU Wage Function?, December 2006

1881 Harry Flam and Håkan Nordström, Euro Effects on the Intensive and Extensive Margins of Trade, December 2006

1882 Panu Poutvaara and Mikael Priks, Hooliganism in the Shadow of the 9/11 Terrorist Attack and the Tsunami: Do Police Reduce Group Violence?, December 2006

1883 Ruud A. de Mooij and Gaëtan Nicodème, Corporate Tax Policy, Entrepreneurship and Incorporation in the EU, December 2006

1884 Johannes Becker and Clemens Fuest, Corporate Tax Policy and International Mergers and Acquisitions - Is the Tax Exemption System Superior?, January 2007

1885 Momi Dahan and Udi Nisan, The Effect of Benefits Level on Take-up Rates: Evidence from a Natural Experiment, January 2007

1886 José García-Solanes, Francisco I. Sancho-Portero and Fernando Torrejón-Flores, Beyond the Salassa-Samuelson Effect in some New Member States of the European Union, January 2007 
1887 Peter Egger, Wolfgang Eggert and Hannes Winner, Saving Taxes Through Foreign Plant Ownership, January 2007

1888 Timothy J. Goodspeed and Andrew Haughwout, On the Optimal Design of Disaster Insurance in a Federation, January 2007

1889 Wim Groot, Henriëtte Maassen van den Brink and Bernard van Praag, The Compensating Income Variation of Social Capital, January 2007

1890 Bas Jacobs, Ruud A. de Mooij and Kees Folmer, Analyzing a Flat Income Tax in the Netherlands, January 2007

1891 Hans Jarle Kind, Guttorm Schjelderup and Frank Stähler, Newspapers and Advertising: The Effects of Ad-Valorem Taxation under Duopoly, January 2007

1892 Erkki Koskela and Rune Stenbacka, Equilibrium Unemployment with Outsourcing under Labour Market Imperfections, January 2007

1893 Maarten Bosker, Steven Brakman, Harry Garretsen, Herman de Jong and Marc Schramm, The Development of Cities in Italy 1300 - 1861, January 2007

1894 Michel Beine, Oscar Bernal, Jean-Yves Gnabo and Christelle Lecourt, Intervention Policy of the BoJ: A Unified Approach, January 2007

1895 Robert S. Chirinko and Daniel J. Wilson, State Investment Tax Incentives: A Zero-Sum Game?, January 2007

1896 Theo S. Eicher and Oliver Roehn, Sources of the German Productivity Demise Tracing the Effects of Industry-Level ICT Investment, January 2007

1897 Helge Berger, Volker Nitsch and Tonny Lybek, Central Bank Boards around the World: Why does Membership Size Differ?, January 2007

1898 Gabriel Felbermayr and Wilhelm Kohler, Does WTO Membership Make a Difference at the Extensive Margin of World Trade?, January 2007

1899 Benno Torgler and Friedrich Schneider, The Impact of Tax Morale and Institutional Quality on the Shadow Economy, January 2007

1900 Tomer Blumkin and Efraim Sadka, On the Desirability of Taxing Charitable Contributions, January 2007

1901 Frederick van der Ploeg and Reinhilde Veugelers, Higher Education Reform and the Renewed Lisbon Strategy: Role of Member States and the European Commission, January 2007

1902 John Lewis, Hitting and Hoping? Meeting the Exchange Rate and Inflation Criteria during a Period of Nominal Convergence, January 2007 
1903 Torben M. Andersen, The Scandinavian Model - Prospects and Challenges, January 2007

1904 Stephane Dees, Sean Holly, M. Hashem Pesaran and L. Vanessa Smith, Long Run Macroeconomic Relations in the Global Economy, January 2007

1905 Richard Jong-A-Pin and Jakob De Haan, Political Regime Change, Economic Reform and Growth Accelerations, January 2007

1906 Sascha O. Becker and Peter H. Egger, Endogenous Product versus Process Innovation and a Firm's Propensity to Export, February 2007

1907 Theo S. Eicher, Chris Papageorgiou and Oliver Roehn, Unraveling the Fortunates of the Fortunate: An Iterative Bayesian Model Averaging (IBMA) Approach, February 2007

1908 Liliana E. Pezzin, Robert A. Pollak and Barbara S. Schone, Efficiency in Family Bargaining: Living Arrangements and Caregiving Decisions of Adult Children and Disabled Elderly Parents, February 2007

1909 Christian Keuschnigg and Soren Bo Nielsen, Self-Selection and Advice in Venture Capital Finance, February 2007

1910 Rune Jansen Hagen and Gaute Torsvik, Irreversible Investments, Dynamic Inconsistency and Policy Convergence, February 2007

1911 Eric A. Hanushek and Ludger Woessmann, The Role of School Improvement in Economic Development, February 2007

1912 Bernard M. S. van Praag, Perspectives from the Happiness Literature and the Role of New Instruments for Policy Analysis, February 2007

1913 Volker Grossmann and Thomas M. Steger, Growth, Development, and Technological Change, February 2007

1914 Margarita Katsimi and Thomas Moutos, Human Capital and the Feldstein-Horioka Puzzle, February 2007

1915 Oliver Roehn, Theo S. Eicher and Thomas Strobel, The Ifo Industry Growth Accounting Database, February 2007

1916 Ian Babetskii, Aggregate Wage Flexibility in Selected New EU Member States, February 2007

1917 Burkhard Heer, Alfred Maussner and Paul D. McNelis, The Money-Age Distribution: Empirical Facts and Limited Monetary Models, February 2007

1918 Yin-Wong Cheung, Menzie D. Chinn and Eijii Fujii, The Overvaluation of Renminbi Undervaluation, February 2007 
1919 Jim Malley, Apostolis Philippopoulos and Ulrich Woitek, To React or Not? Fiscal Policy, Volatility and Welfare in the EU-3, February 2007

1920 Mattias Polborn, Competing for Recognition through Public Good Provision, February 2007

1921 Lars P. Feld and Benno Torgler, Tax Morale after the Reunification of Germany: Results from a Quasi-Natural Experiment, February 2007

1922 Robert S. Chirinko and Huntley Schaller, Fundamentals, Misvaluation, and Investment: The Real Story, February 2007

1923 Benno Torgler and Friedrich Schneider, Shadow Economy, Tax Morale, Governance and Institutional Quality: A Panel Analysis, February 2007

1924 Adrian Pagan and M. Hashem Pesaran, On Econometric Analysis of Structural Systems with Permanent and Transitory Shocks and Exogenous Variables, February 2007

1925 Hans-Werner Sinn, The Welfare State and the Forces of Globalization, February 2007

1926 Michael Smart, Raising Taxes through Equalization, February 2007

1927 Øystein Foros, Kåre P. Hagen and Hans Jarle Kind, Price-Dependent Profit Sharing as an Escape from the Bertrand Paradox, February 2007

1928 Balázs Égert, Kirsten Lommatzsch and Amina Lahrèche-Révil, Real Exchange Rates in Small Open OECD and Transition Economies: Comparing Apples with Oranges?, February 2007

1929 Aleksander Berentsen and Cyril Monnet, Monetary Policy in a Channel System, February 2007

1930 Wolfgang Ochel, The Free Movement of Inactive Citizens in the EU - A Challenge for the European Welfare State?, February 2007

1931 James K. Hammitt and Nicolas Treich, Statistical vs. Identified Lives in Benefit-Cost Analysis, February 2007

1932 Wilhelm Kohler, The Bazaar Effect, Unbundling of Comparative Advantage, and Migration, February 2007 